\title{
The Effect of Japanese Animation Series on Informal Third Language Acquisition among Arabic Native Speakers
}

\author{
Sara S. Alsubaie ${ }^{1} \&$ Abbad M. Alabbad ${ }^{2}$ \\ ${ }^{1}$ Department of Linguistics and Translation Studies, College of Languages and Translation, King Saud \\ University, Riyadh, Saudi Arabia \\ ${ }^{2}$ Faculty of Linguistics and Translation Studies, College of Languages and Translation, King Saud University, \\ Riyadh, Saudi Arabia \\ Correspondence: Sara S. Alsubaie, Department of Linguistics and Translation Studies, College of Languages and \\ Translation, King Saud University, Riyadh, Saudi Arabia.
}

Received: June 10, 2020

Accepted: July 6, 2020

Online Published: July 14, 2020

doi: 10.5539/elt.v13n8p91

URL: https://doi.org/10.5539/elt.v13n8p91

\begin{abstract}
Recent studies on language acquisition and motivation have targeted Japanese language learners in a formal educational context, with less attention paid to learners who study Japanese informally. The current study aims to investigate the impact of Japanese animations in the context of informal third language acquisition. It targets the native speakers of Arabic who are interested in learning Japanese as a third language (L3), and investigates the motivations of Arab teenagers and young adults to learn Japanese. Further, the paper also focuses on examining aspects of Japanese language proficiency among teenagers and young adults, including vocabulary enhancement and grammar competence. The methodology used in the current study is twofold: an online survey questionnaire adopted from Armour and Iida (2016), followed by an engaging experiment in which participants were divided into two groups (reality anime group vs. action anime group) in order to examine the effectiveness of anime selection in boosting proficiency level. The findings of the online survey indicate that Arabic native speakers are highly motivated to learn Japanese, while the experiment results confirm that the type of anime and consistency of exposure do support the acquisition process. Further, the study concluded that consumption of anime series contributes to the learning process and facilitates learners' proficiency in general and vocabulary learning in particular. However, it remains unknown whether or not Arabic native speakers' motivations lead to their enrollment into formal Japanese foreign language education. Avenues for future research and implications are also presented toward the end of the paper.
\end{abstract}

Keywords: Arabic native speakers, informal learning, Japanese animations, L2 motivational self-system theory, popular culture, third language acquisition, vocabulary and grammar learning

\section{Introduction}

The Japanese popular culture of anime is an emerging topic in the field of third language acquisition. The term "anime" refers to any animated series that are produced by Japanese production companies, which constitute almost $60 \%$ of the world's animated TV shows (Napier \& Susan, 2016). The artistic style of Japanese animations first emerged in the 1960s and then gained popularity internationally in the late twentieth century due to the high quality of graphics and sounds. Anime is usually characterized by a continuous and detailed story line, strong character development, and a creative and distinctive artistic style. Moreover, it addresses a variety of issues including friendship, honor, respect, ambitions, and overcoming obstacles. The anime industry comprises over 400 production companies that have a global reach. Only a handful of studies has emphasized the link between the Japanese popular culture of anime and foreign language education. Previous studies have particularly targeted Japanese language learners in a formal educational context, and little attention is given to those who study the language informally.

The current study aims to explore the impact of Japanese animations on third language (L3) acquisition. It targets the native speakers of Arabic who are interested in learning Japanese informally as their L3; moreover, the study attempts to investigate the motivations of these learners for doing so as well as examines different aspects of their language competence. Thus, the significance of the current study in contrast with previous work is that it does not merely focus on vocabulary development but also on grammar competence. Further, it uses the 
Japanese anime series as an informal learning tool in order to test the hypothesis that Arabic native speakers have considerably high interest in learning Japanese and that they can develop vocabulary and grammatical knowledge simultaneously through exposure. Further, the study proposes that the type of content that learners are consistently exposed to would support their acquisition process. The type of content is identified according to the genre of anime such as action, comedy, drama, fantasy, sci-fi, mystery, and slice of life. Slice of life is a category of anime that portrays a sequence of events that reflects emotional and insightful real-life situations, also referred to as reality animations. Specifically, this study focuses on comparing action animations with reality animations in facilitating the learning process. Thus, the study seeks to answer the following research questions:

- To what extent are Arabic native speakers motivated to learn Japanese as a third language?

- How does the type of content that learners are exposed to impact vocabulary development and grammar competence?

- What are the implications and future directions of informal language learning in general and animations as a learning tool in particular?

\section{Literature Review}

\subsection{Theoretical Framework of Informal Language Learning}

One of the operational definitions in this study is the term "informal learning." Generally, the learning process can be classified under one of three types of learning: formal learning, non-formal learning, or informal learning (Mocker \& Spear, 1982). According to the definitions provided by the European Commission (2001), the three types of learning are defined in the following manner.

First, formal learning is an intentional type of learning that is highly structured in respect to the content, learning time, and learning objectives. It is facilitated by a teacher or instructor, typically offered by educational institutions, and results in certification. Second, non-formal learning is also intentional and structured with respect to the content, learning time, and learning objectives. However, it is neither offered by educational or training institutions, nor does it result in certification. Third, informal learning is incidental or nonintentional type of learning (in certain cases, it can be intentional) that is unstructured and controlled by the learner's motivation and needs. It is a result of everyday exposure, activities, or leisure and typically does not result in certification.

In this study, formal and non-formal learning are not considered; the focus is only on informal learning. Several researchers (Coffield, 2000; Mahoney, 2001; Van Marsenille, 2015 \& 2017; Kukulska-Hulme, 2015) have indicated that informal learning is less frequently researched than formal learning and have also emphasized the significance of informal learning as part of the overall learning process. Further, Bahrani (2011) demonstrated the link between informal language learning and certain language learning theories. In essence, the comparison between psychologically oriented approaches (behaviorism and innatism) and socially oriented approaches (interactionist and constructivist) in relation to informal second language acquisition is presented in the following table:

Table 1. The relationship between informal language learning and other language learning theories (cited from Bahrani, 2011)

\begin{tabular}{ccccc}
\hline $\begin{array}{c}\text { Theories of } \\
\text { language learning }\end{array}$ & Behaviorism & Innatism & Interactionist & Constructivist \\
\hline $\begin{array}{c}\text { Informal language } \\
\text { learning }\end{array}$ & $\begin{array}{c}\text { Not suitable, } \\
\text { because it requires } \\
\text { repetition and drills } \\
\text { even in an informal } \\
\text { setting. }\end{array}$ & $\begin{array}{c}\text { Suitable, because } \\
\text { language can be } \\
\text { learnt through } \\
\text { exposure in an } \\
\text { informal setting. }\end{array}$ & $\begin{array}{c}\text { Suitable, because } \\
\text { the focus is } \\
\text { primarily on the } \\
\text { meaning, which } \\
\text { supports informal } \\
\text { learning. }\end{array}$ & $\begin{array}{c}\text { Suitable, because } \\
\text { the focus is on } \\
\text { exposure. It can be } \\
\text { supported based on } \\
\text { learner autonomy. }\end{array}$ \\
\hline
\end{tabular}

According to Bahrani (2011), the behaviorist approach is best suitable for explicit teaching and computer-assisted instruction (i.e., formal learning), since it involves imitation, repetition, reinforcement, and feedback (Skinner, 1957; Ellis, 1999). The innateness approach contrasts with behaviorism, which refers to the cognitive ability to learn a language through exposure to sufficient input (Chomsky, 1965, 1993). This language input can be obtained from the learner's surroundings through parents, peers, audio/visual media, or the online network. Therefore, behaviorism cannot explain the complexity of language learning only through habit-formation. According to the interactionist approach, learning is achieved through social interaction with 
competent speakers and the learning environment is not limited but rather dynamic, flexible, and innovative (Long, 1983; Pica, 1994). Moreover, Bahrani (2011) has argued that the interactionist approach is the most typical form of informal language learning amongst all the other approaches. However, the interactionist approach is not applicable in this study due to the lack of communication between Arabic participants and Japanese native speakers in the context of this study. Consequently, Japanese animation series are considered an alternative authentic source of language input. Last, but not least, is the constructivist approach, in which language learners create new ideas based on their previous and current knowledge (Cook, 1996). According to the constructivist view, language learning is an active, creative, and socially interactive process and involves exposure to language in authentic contexts.

In summary, in this study, informal language learning cannot be based on the behaviorism or interactionist approaches but rather on innatism and constructivist approaches since both the latter approaches emphasize that informal language learning must be unstructured and incidental, which mostly correlates with Bahrani's view.

\subsection{Motivation Theories and Second Language Acquisition (SLA)}

The motivation to learn a new language is an elusive construct (Chik, 2019). In other words, a learner may be motivated to learn a new skill in a formal educational context but fails to extend the learning process in an informal context or vice versa (Benson, 2015). The word "motivation" has numerous definitions in extant literature. Dörnyei and Ushioda (2011) confirm that motivation is related to "the choice of a particular action, the persistence with it, and the effort expended on it." In a general sense, a language learner may choose a particular "action" from a great variety of options (e.g., using an anime series, TV shows, or online network resources), which consequently impacts his or her "persistence and effort" associated with that action (i.e., may extend or contract language learning). Several studies in psychology have defined various kinds of motivation including intrinsic vs. extrinsic, instrumental vs. integrative, and interactive (Deci \& Ryan, 1985; Gardner \& Lambert, 1972; Sade, 2003). However, these studies have divided motivation into two separate linear dimensions: individually vs. socially oriented motivations, which cannot accommodate for the complexity of motivation in its current state (Sade, 2011).

L2 motivation has evolved rapidly and undergone different theoretical phases since the 1960s. Recent developments in SLA have examined motivation from a new perspective, thereby leading to the emergence of three motivational theories that comprise the nature of constant learning. These theories are developed not only to account for L2 learning but also to accommodate the learning of a third, foreign, additional, heritage, global language, lingua franca (Note 1), or any basic language skills (Dörnyei \& Ushioda, 2011).

There are various emerging SLA motivational theories: One of these theories is a theory proposed by Ushioda (2009), that is, "a person-in-context relational view of motivation." In this theory, Ushioda developed a relationship between motivation on one hand and self and context on the other, which contradicts the shortcomings of old linear approaches of motivation (e.g., treating self and context as separate dimensions). She argues that language learners are real people who are located in certain cultural and historical contexts and whose motivations and identities are shaped by these contexts and vice versa. Her idea is to abandon the theoretical abstraction of learners' characteristics and to emphasize the existence of multiple contextual elements that correlate with motivation. However, developing a functional, useful, and realistic strategy for the analysis of motivation remains a challenge to this approach (Dörnyei \& Ushioda, 2011).

The second theory is suggested by Dörnyei (2005 \& 2009a) and is known as the L2 motivational self-system. This theory has three main components: The Ideal L2 Self, the Ought-to L2 Self, and the L2 Learning Experience. The Ideal L2 Self is a typical reflection of one's ideal self. The learner's "ideal L2 self" is a strong motivation toward learning another language, since the learner has the desire to shrink the gap between the actual self and ideal self. Moreover, traditional approaches such as integrative and internalized instrumental motivations can actually be classified under this component. The Ought-to L2 Self refers to the attributes that a learner believes he/she must possess in order to meet social or institutional expectations and to prevent potential negative outcomes. This component requires extrinsic instrumental motives. In other words, this component is less internalized. Finally, the L2 Learning Experience is a situated executive motivation that comprises the learner's experience in a particular learning environment, whether formal or informal (e.g. impact of instructors, peers, curriculum, media, etc.). Therefore, the Ideal L2 Self and the L2 Learning Experience are the most significant components of this theory on account of their reliability in predicting the learner's motivation and achievement (Csizér \& Kormos, 2009; Taguchi et al., 2009).

Last but certainly not least is an approach to motivation from a complex dynamic systems perspective. This approach was developed by Dörnyei (2009b) in order to breakdown motivation into its essential components, 
thereby aiming to achieve a model that can account for all motivational phenomena. The complex dynamic system model suggests that motivation, cognition, and affect are inseparable dimensions. There is no single explanation for any motivated behaviors. What poses a challenge to this approach is to identify a level of analysis that captures the three dimensions in one situation. In fact, all we need to do is to dig deeper into motivation and "ask the right questions" (Dörnyei \& Ushioda, 2011).

To sum up, there has been a steady flow of motivational theories in the previous few decades. The integration of motivation from psychology into SLA is a contemporary movement toward language learning and teaching. It has been suggested that language learners are driven by multiple-dimensional factors, like the idea of possible selves that reflects the learner's imagination and fantasy and the idea of multiple contexts and affects, which also possibly includes cognitive abilities. The aforementioned theories may help in explaining why Arabic native speakers are attracted and motivated to learn the Japanese language.

\subsection{Previous Studies on Japanese Animations and Motivation}

Throughout literature, the impact of animation series as an informal learning tool has not been studied thoroughly (Spindler, 2010; Han \& Ling, 2017). Previous studies have focused on the use of anime clips in a formal educational environment, where the content is manipulated and controlled; little attention is given to those learning Japanese informally (Armour \& Iida, 2016). Moreover, certain researchers have proposed different models and techniques that can be used for educational purposes by adopting anime in Japanese foreign language classrooms (Han \& Ling, 2017), while others have questioned the effectiveness of this method and have discussed a few advantages and disadvantages of its usage in classrooms. Further, a few studies have highlighted the motivational factors of learning Japanese language as L2 (Fukunaga, 2006; Allison, 2006; Shamoon, 2010; Swenson, 2010; Northwood \& Thomson, 2012).

Most anime-related studies are rather new. Several researchers have discussed the positive impact of animations in increasing learners' linguistics competence (Arikan \& Taraf, 2010; Velez Gea, 2013; Munir, 2016). For example, one study by Bahrani and Soltani (2011) emphasized the effectiveness of anime videos in providing visual and auditory information. Visual information is usually processed by the right-side of the brain, which is concerned with analyzing holistic and artistic data. On the other hand, auditory information is analyzed by the left-side of the brain, which usually performs analytical calculations and interpretations. In contrast, traditional learning tools (e.g., paper-based methods) extensively stimulate the left hemisphere of the brain and make the learning process dull and boring. Moreover, anime characters put language into use by implementing Japanese expressions in suitable situations or events. Conversations and interactions among characters as part of the storyline provide the learner with rich, comprehensive input. Further, the use of animations adds entertainment to the learning process, which makes the educational environment enjoyable.

Only a few studies have investigated Japanese language literacy and vocabulary development. Fukunaga (2006) evaluated the influence of anime on the literacy level of American students in terms of aspects such as word recognition, listening, and pronunciation. Her research concluded that the advantage of anime lies in developing a learner's overall literacy, particularly listening skills. In addition, another research by Kayaoglu and Akbas (2011) investigated whether there was a difference between learning vocabulary through animations as compared to learning vocabulary through traditional methods (i.e., the paper-based method). They conducted an experiment in which they randomly divided pre-intermediate students into two groups: experimental and control groups. Although the statistical results showed no significant differences between the two groups in the post-test scores, the experimental group outperformed the traditional group in vocabulary learning. The study concluded that animations contributed to better performance of the students. However, English as a foreign language (EFL) instructor must pay attention to the type of content presented and to the learners' proficiency levels.

Devi (2005) highlighted a few points in favor of the effectiveness of utilizing animations in language learning. Among the positive outcomes of the study were that the learner's motivation as well as the contextual comprehension both increased. The study also found that animations support reducing affective filters (e.g., school curriculum) and also help to decrease anxiety levels. In addition, animations also help the retention of new concepts as compared to traditional learning methods. However, the study encountered a few challenges as well. The researcher found that utilizing animation in language learning may have negative effects such as causing distractions and repeated watching, which may negatively affect health and well-being on account of extensive exposure to electronic devices. In addition, Matsumoto (2007) investigated the peak learning experience (Note 2) among American students who were studying Japanese as a foreign language. The researcher reported that, from the students' perspective, their most positive experience was being understood by Japanese natives, while the negative experience was losing motivation if their learning did not progress. 
Motivational factors in Japanese language learning are still part of an open area for investigation among researchers. One view supports that the popular culture of Japanese anime has motivated learners to enroll into formal Japanese learning classes. Numerous advocates of this view have claimed that anime series have a positive effect on students' enrolment into Japanese as a foreign language (JFL) courses (Fukunaga, 2006; Allison, 2006; Shamoon, 2010; Swenson, 2010; Northwood \& Thomson, 2012). Data provided by The Japanese Foundation (2011) also support this view. Over 13,000 learners of Japanese language participated in a survey that revealed that $50.6 \%$ of the respondents are interested in learning the language because of anime and manga rather than studying Japanese history and literature. On the contrary, a more recent study by Armour and Iida (2016) supports a contrasting view. They investigated whether or not Australian anime lovers are motivated to learn Japanese and the findings concluded that the participants' interest in anime did not necessarily motivate them to enroll in Japanese language education. However, the study was conducted in an Australian context and it is possible that the findings cannot be generalized.

Thus, the use of animation series as a learning tool is a rich and relatively new subject for research. Most previous studies have not come to a clear conclusion regarding learners' motivations in learning Japanese or regarding learners' linguistic competence. Further, previous work has focused on formal education and research that addresses Arabic native speakers who are learning Japanese informally remains limited. The current study aims to investigate the motivation of Arabic natives learning Japanese as a third language. The study hypothesizes that learners from an Arabic language background are motivated to learn Japanese due to multidimensional factors. In addition, the study also discusses the linguistic competence of and whether using animations would enhance the vocabulary competence of Arabic natives who are learning Japanese. It will also highlight the influence of learning progress in grammatical aspects and the type of content (i.e. genre) during consistent exposure to Japanese animation series.

\section{Methodology}

The current study adopts a sequential mixed research design in order to obtain authentic data. The data collection procedure included two data collection methods; first the researcher distributed an online survey questionnaire targeting a large number of people across several Arabic countries. Based on the data collected from the survey, participants were elected to engage in an experiment according to specific sampling criteria. The following subsections present a detailed description of the methods employed.

\subsection{The Online Survey Questionnaire}

The first data collection method implemented in this study was an online survey questionnaire; this was done due to reasons of practicality, suitability, and convenience. According to Wright (2005), in comparison to the ordinary paper-based survey, the online survey method has more benefits but still has a few drawbacks. Wright reported that an online survey enables researchers to reach a large number of targeted respondents worldwide and also empowers respondents to reveal their honest opinions on the subject at hand compared to a paper-based survey. On the other hand, he raised some concerns particularly with regard to receiving repeated responses from a single participant, collecting inaccurate geographical information, or being biased to a certain group of people. However, in our case here, we found the online survey method more appropriate in the context of the study for the following reasons:

a) The study targets only anime fans that are located in different Arabic countries and territories, which makes it much easier to reach them via the online survey rather than a paper-based survey.

b) Most, if not all, members of the targeted sample rely on Internet resources and websites to keep up with their favorite anime series. Therefore, the Internet is also used to reach a wider range of age varieties in this study.

c) Members of different anime communities help in spreading the online survey faster using their available facilities.

d) Online surveys are more economical with respect to the time and effort of administration compared to the paper-based surveys for both researchers and respondents.

\subsubsection{Participants}

The survey targeted Arabic native speakers from 14 different countries including Saudi Arabia, United Arab Emirates, Kuwait, Oman, Yemen, Egypt, Sudan, Alegria, Morocco, Syria, Palestine, Iraq, Jordan, and Comoro Islands. A total of 215 responses were received. However, 11 responses were excluded from the data since 3 of them were repetitive, and 8 responses were submitted by subjects who have studied Japanese language formally and hold certificates, thereby not meeting the current study's sample requirements. Hence, the remaining 204 
responses were considered as the qualified participants for the study. The participants included 82 males and 122 females, aged from 15 to 35 years. The majority of the participants did not receive formal Japanese education nor had they traveled or lived in Japan before. The following table summarizes the information of the targeted sample in the survey.

Table 1. Respondents' demographic information in the online survey questionnaire

\begin{tabular}{llllll}
\hline Gender & Age group & Country & L1 & L2 & Education level \\
\hline $\begin{array}{l}\text { Males }=\mathbf{8 2} \\
\mathbf{( 4 0 . 2 \% ) .}\end{array}$ & $(15-19)=38.2 \%$ & $77 \%$ from Saudi Arabia. & $\begin{array}{l}100 \% \\
\text { Arabic }\end{array}$ & $\begin{array}{l}93.1 \% \text { speak } \\
\text { English. }\end{array}$ & High school $=39.7 \%$ \\
& $(20-24)=45.6 \%$ & & & Diploma $=5.9 \%$ \\
& & & & & \\
Females $=\mathbf{1 2 2}$ & $(25-29)=11.3 \%$ & $\begin{array}{l}23 \% \text { from other Arab } \\
\text { countries. }\end{array}$ & & French. & Bachelor's $=49.5 \%$ \\
& & & & Master's $=4.9 \%$ \\
\hline
\end{tabular}

\subsubsection{Survey Design and Instruments}

The survey was designed to follow a mixed data collecton approach,which combines both quanitative and scale or -qualitative data collection methods. The quaniatative method is implemented in the form of Likert ended -plemented is in the form of openchoice questions, whereas the qualitative method was im-multiple quesions to elicit the honest views of the respondents. The survey questionnaire is adapted from Armour and Iida (2016). However, a few changes were made by deleting certain irrelevant questions and adjusting others to fit the Arab culture and be easily understood by the respondents. The general design of the online survey includes four sections: Section (1) is an introduction that illustrates the aim of the study; Section (2) elicits the respondents' general demographic information; Section (3) includes questions regarding their interests, duration of access, and resources of Japanese anime series; and Section (4) deals with informal Japanese language learning, motivation, and skills. Most of the questions were multiple-choice questions, but a few others were open-ended questions that were included in the survey in order to enable participants to better express their perspectives (Appendix A).

\subsubsection{Procedures and Data Analysis}

The survey questionnaire was designed using Google Forms and was distributed online for a duration of approximately three weeks in order to approach a large number of potential respondents. The data collected from the survey were converted into sheets and analyzed using various data analysis tools and programs.

\subsection{Experiment}

The second data collection method adopted in this study was in the form of an experiment. Based on the data obtained from the survey, it was important to dig deeper into motivation and test the effectiveness of anime as a language learning tool. The nonrandomized pretest and posttest methods were appropriate for use in the current study for several reasons (Salkind, 2010).

a) They provide an initial score from each individual prior to the exposure of any effect-in this case, Japanese animations.

b) They also produce a post-effect score that predicts the amount of change that occurred after watching animations.

c) They are rather practical in measuring the change not only between-subjects but also within-subjects.

d) The pretest scores could be used as controls for each participant, and the posttest scores can identify the experimental outcomes.

e) In order to avoid internal and external validity issues associated with randomization, nonrandomized pretest and posttest methods are adopted (i.e. participants are equally divided into two groups). 


\subsubsection{Participants}

The experiment included 51 participants from 8 Arabic countries including Kingdom of Saudi Arabia (KSA), the United Arab Emirates (UAE), Bahrain, Oman, Yemen, Syria, Libya, and Sudan. The participants were 23 males and 28 females and were selected on the basis of specific sampling criteria, which is described below.

a) All participants are Arabic native speakers who also speak English/ French as their L2.

b) All participants have the ability to understand some basic Japanese and they can read and comprehend simple sentences written in Kana and some basic Kanji, they also can listen to short conversations and comprehend simple utterances.

c) None of the participants in the experiment are enrolled in JFL courses or institutes.

d) None of the participants are Japanese heritage speakers, nor they have lived or studied in Japan before.

Initially, there were 60 participants in the experiment and they were carefully divided into two equal groups in order to avoid gender differences and to measure the variable of anime type (i.e., the between-subjects variable). However, nine participants withdrew from the experiment in the first week. Consequently, their pretest results were excluded from the analysis and the normality test was conducted using the SPSS program in order to ensure that the participants are normally distributed in both groups. The remaining participants were assigned to group $A=$ reality anime $(n=25)$ and group $B=$ action anime $(n=26)$. The ages of the participants ranged from 19-34 years and the gender distribution was almost equal in both groups (Group A had 11 males and 14 females, while Group B had 12 males and 14 females). The normality test results in the table below show that all p-values were greater than the significance level of 0.05 , which indicates that data follow a normal distribution.

Table 1. Tests of Normality

\begin{tabular}{cccccccc}
\hline & \multicolumn{4}{c}{ Kolmogorov-Smirnov $^{\mathrm{a}}$} & \multicolumn{3}{c}{ Shapiro-Wilk } \\
\hline & Group & Statistic & $\mathrm{df}$ & Sig. & Statistic & $\mathrm{df}$ & Sig. \\
\hline Pretest Scores & A & 0.102 & 25 & $0.200^{*}$ & 0.965 & 25 & 0.511 \\
& B & 0.109 & 26 & $0.200^{*}$ & 0.975 & 26 & 0.753 \\
Posttest Scores & A & 0.112 & 25 & $0.200^{*}$ & 0.965 & 25 & 0.519 \\
& B & 0.119 & 26 & $0.200^{*}$ & 0.965 & 26 & 0.508 \\
\hline
\end{tabular}

\section{*. This is a lower bound of the true significance. \\ a. Lilliefors Significance Correction \\ 3.2.2 Material}

In the current study, action anime and reality anime series (Note 3) were selected for the content. According to Hand and Ling (2017), the selection of anime must satisfy a learner's needs. Hence, participants initially joined the study in order to improve their overall skills, particularly focusing on learning new vocabulary and grammar autonomously. Although a few subjects withdrew from the experiment, they had expressed their desire to join the experiment in order to achieve some linguistic improvements. Moreover, other criteria have been indicated by Syaifuddin (2010) and these criteria are consistent with the selected animations in terms of the following aspects: a) the selected anime series are culturally appropriate; b) the duration of the anime series exceeds 42 hours, which is the time required to accomplish the experiment based on the Japanese Language Proficiency Test (JLPT)preparation timeframe; c) the selected anime series are publicly available online for free on numerous websites, d) the visual quality of the anime is high in terms of drawings, characters voices, and written subtitles; e) the anime selection is not only compatible with the test but also with the age and linguistic level of the participants (i.e., participants were classified as Japanese N5 level, which is the first and easiest level that is usually used to classify beginners).

With regard to the pedagogical value, the story lines in both anime types are enriched with numerous vocabulary words and grammatical forms that participants can benefit from. Conversations and dialogues among characters include frequent words that participants are familiar with and new words that they may have encountered for the first time. In terms of grammar, instances of particles usage, negation, conjugation, word order, question formation, etc. are presented in various scenes. Further, for reasons of convenience and practicality, the participants follow the experiment from home, as instructed. 


\subsubsection{Instrument}

The instrument used in this experimental study to assess participants was a questionnaire comprising 45 questions that were selected from JLPT samples taken from a specialized website ( jtest4you, 2014). These questions reflect N5 Japanese proficiency level, which is specified for assessing beginners. The questions were collected and verified with the help of three experts in Japanese language and were divided into two parts - the first part included 30 vocabulary questions and the second part included 15 basic grammar questions.

The test was evaluated for content and validity in order to ensure that a) items in the test reflect the study objective, b) the test level corresponds to the expected language level of the participant and was clear for all participants, c) the questions were rather balanced and were not biased toward any specific group, d) the test items sufficiently cover the content in terms of selecting common vocabulary and grammar, e) the grading system is clear in assigning one point for a correct answer and zero for an incorrect answer.

Moreover, the internal consistency of the test was checked using SPSS program's Cronbach's alpha reliability function. The Cronbach's alpha reliability coefficient of items in the test was measured. This reliability coefficient normally ranges between 0 and 1 . The results indicate that Cronbach's alpha value $=0.939$ out of 1.0 , which implies that the test is not only consistent but also has a high level of reliability, which is in accordance with George and Mallery (2003).

\subsubsection{Design}

The current study implemented a between-subjects (subjects-inter) design in which participants in different groups were assigned to watch different anime genres. Group A participants were assigned to watch reality anime series, and Group B participants were assigned to watch action anime series; the experiment lasted for three weeks. The time of exposure was constant for both groups and was a total of 42 hours distributed consistently over 21 days with a rate of 2 hours of daily consumption. The independent between-group variables were the conditions of the anime genre. The dependent variables were included within the test design, which comprises the vocabulary and grammar sections. The vocabulary section includes items of various parts of speech such as nouns, verbs, and adjectives, while the grammar section focuses on basic rules. For example, the use of adverbs, prepositions, particles, tenses, negations, conjunctions, and Japanese word order. Both groups took a pretest before the utilization of anime series and a posttest immediately after finishing them. The test design was the same in the pretest and posttest phases (Appendix B).

\subsubsection{Procedures}

Participants in both groups took an online pretest distributed using Google Forms. They were given 45 minutes to answer 45 multiple choice questions. In the tests, participants were asked to perform two tasks: the first was a picture-naming task including nouns, verbs, and adjectives in Japanese, and the second involved a grammar task that dealt with basic Japanese grammar rules. After completing the pretest, participants engaged in the informal learning phase in which they were required to watch anime series for two hours consistently in a daily basis until the end of the experiment. During the first week, nine participants withdrew from the experiment, but their withdrawal did not influence the results. Over the course of three weeks, a total of 84 episodes were completed. After this phase, participants were given the same test immediately as a posttest in order to measure the amount of change in their Japanese proficiency level; they were also given the same amount of time to complete this test as that in the pretest. According to Tomlinson (2011), the production phase took place after extensive exposure. Since there were no instructions to be enforced, this technique enables the participants to notice the mismatch between what they do and what proficient Japanese anime characters typically do.

\subsubsection{Data Analysis}

In terms of the pretest and posttest analysis, one correct answer is counted as one point and an incorrect answer is given zero. The ultimate test score is 45 points. After the scores were calculated for each participant, the data were statistically analyzed using the SPSS t-test.

\section{Results}

\subsection{Survey Results}

This section provides the detailed findings obtained from the online survey. First, the participants' interest in Japanese is presented, followed by an explanation regarding their motivations. Then, the informal learning techniques they used and the types of anime they usually watch are presented, including a few advantages and disadvantages of the techniques that were indicated by the participants. 


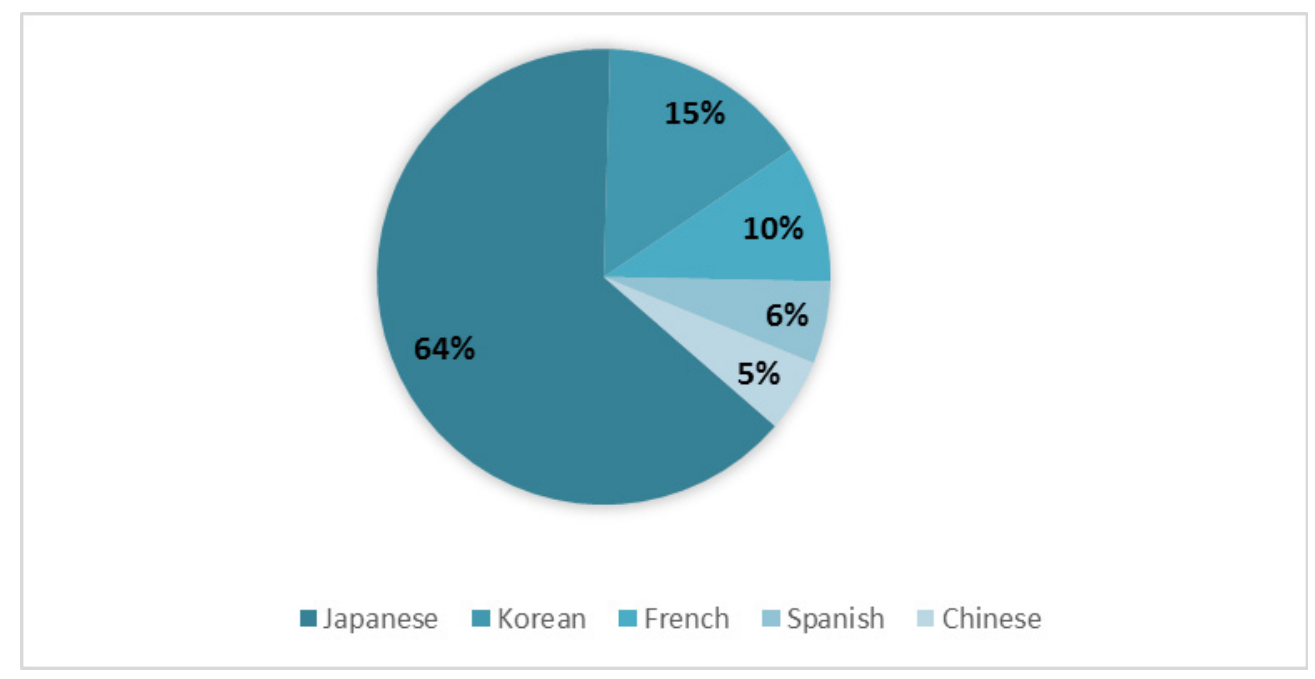

Figure 1. Interesting languages to learn as L3*

*Respondents can choose one or more languages, total responses received $=272$.

The total number of responses is 204 and the gender distribution reveals that there are more females participants $(\mathrm{n}=122,59.8 \%)$ than males $(\mathrm{n}=82,40.2 \%)$, yet gender differences are not considered as an intervening variable in this study. When participants were asked about their L3 language interest, the results indicate that $64 \%$ were interested in learning Japanese $(\mathrm{n}=174)$, while $15 \%$ were interested in learning Korean $(\mathrm{n}=41)$, followed by $10 \%$ for French $(n=27)$, also $6 \%$ for Spanish $(n=16)$, and the least attractive was Chinese, which only accounted for $5 \%$ of responses $(n=4)$, as illustrated in Figure 1 above. Moreover, when participants were asked about their previous experiences with Japan and the Japanese language, only 1 participant from among 251 responded that they had visited Japan before and 8 participants revealed that had taken formal Japanese learning courses. With regard to the use of technology and internet, $52 \%$ of respondents used a smartphone to watch Japanese animations, $36 \%$ used a personal computer or laptop, while $7 \%$ used a tablet device, and only $5 \%$ used other types of devices (e.g., smart TV, projector, or PlayStation).

Moreover, respondents were asked how often they watch anime series, the majority responded "every day," followed by "once in few days," and very few answers were "once a week." With regard to the average time that is spent daily on watching anime episodes, the responses were divided into four groups, two of which are almost equal: "three hours per day" and "two hours per day," followed by "one hour a day" and lastly, "half an hour daily." Surprisingly, the respondents indicated that their growing interest in Japanese animations began over five years ago, which signifies a continuous motivation. In essence, the general picture of respondents in this study indicates that Arab teenagers and young adults, whether males or females, have a high consumption of anime series due to ease of access and potential interest in learning Japanese as a third language regardless of their limited experience in visiting the country and almost absence of contact with Japanese native speakers.

With regard to the respondents' motivations toward learning Japanese language and other anime-related factors, the data indicate the following aspects. The initial motivations of respondents to watch Japanese anime and learn the language are varied. Essentially, the participants' motivations to watch anime either revolved around TV programs $(38.9 \%$ ), were driven by the influence of their peers and relatives $(34.8 \%)$, or were manifested from the expansion of the Internet and the existence of online anime communities, fan blogs, and websites (26.3\%). These reasons result in the emergence of other factors that encouraged such people (i.e., anime fans) to consider learning Japanese as L3. The data indicate that $49 \%$ confirmed that their general interest in Japanese culture encouraged them to learn the language; $19 \%$ indicated that the uniqueness of the language is a strong motive and that there is no other reason compared to $17 \%$ who were motivated to learn the language in order to watch animations without subtitles or dubbing; only $8 \%$ had future plans to work or study in Japan; and $7 \%$ were motivated to learn Japanese in order to improve their drawing skills (Figure 2). 


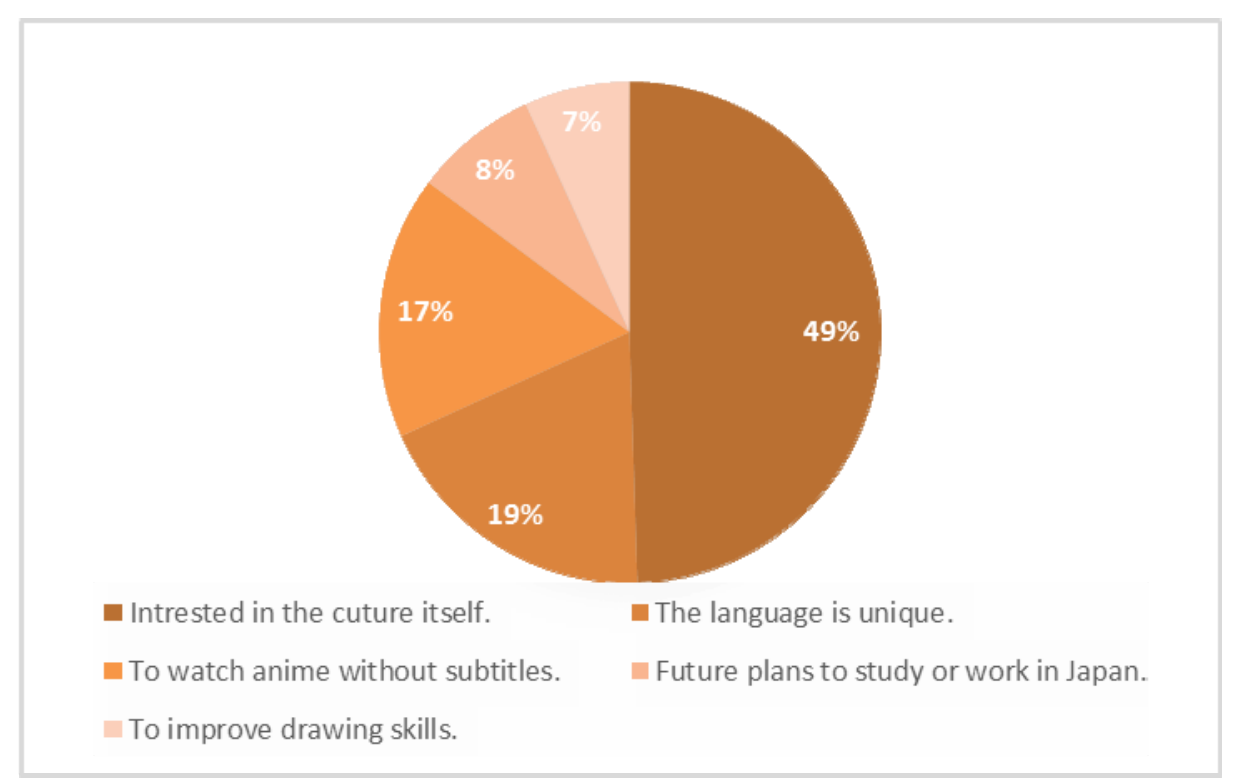

Figure 2. Motivations to learn Japanese

In order to further explain the link between Japanese anime and motivation to learning Japanese, the respondents were asked to determine which kind of Japanese products they looked up to the most, whether it is anime series alone, or manga alone, or both. The responses revealed that the majority consumed both anime and manga but they preferred anime over manga $(n=107)$, followed by preference of only anime series $(n=49)$, while others had no preference at all and consumed both anime and manga equally $(\mathrm{n}=35)$; unexpectedly, a few respondents preferred manga sketched stories over anime series $(n=13)$. Moreover, participants were asked to specify the language in which they usually watched anime, and a total of $87.3 \%$ agreed that the language used is spoken Japanese with Arabic subtitles, compared to $10.8 \%$ who used spoken Japanese with English subtitles, and only $2 \%$ declared that they understood spoken Japanese without any translation. It is obvious that none of the respondents actually favored dubbing in any way or watch anime with Japanese captions. Nevertheless, when participants were asked about how long they had been learning Japanese informally, 57.4\% declared that they had begun informal learning two years ago or over; while $21.1 \%$ claimed that they began informal learning recently, which meant almost three months ago; and $16.2 \%$ stated that they had begun almost one year ago; and very few stated that they had begun learning Japanese almost six months ago (5.4\%).

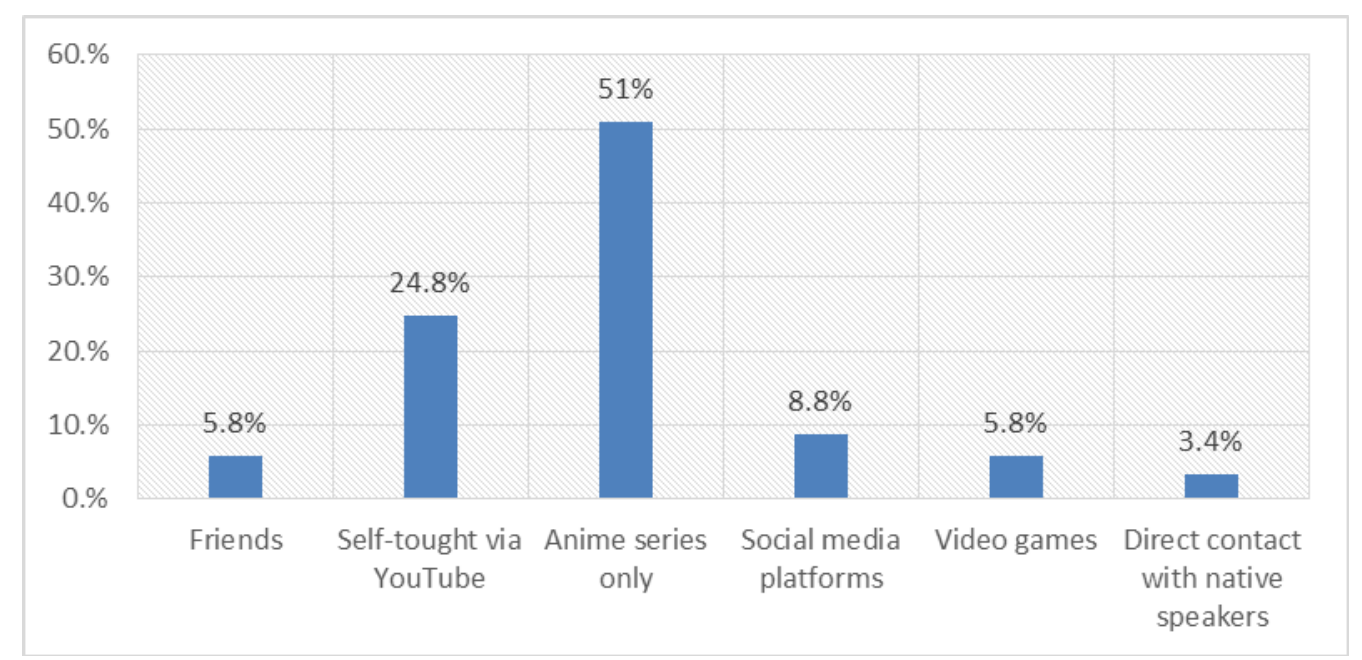

Figure 3. Informal learning techniques*

* Respondents could choose one or more methods out of 6 methods, and a total of 327 responses were received for this question. 
With regard to the participants' informal learning techniques, the genre of anime, and Japanese language learning skills, there are few observation notes that can be derived from the data. First, with regard to the informal learning techniques used to learn Japanese, the majority of the participants (51\%) have confirmed that they only learned Japanese through long exposure to anime. According to the data, the average time of exposure was 2-3 hours per day and this number increased during weekends and holidays. Further, $24.8 \%$ were self-taught via YouTube, $8.8 \%$ via social media, and 5.8\% were observed to be learning Japanese through friends and video games, and a small proportion was noticed in learning Japanese through direct contact with native speakers only constituting 3.4\% of the total responses (Figure 3). Second, when participants were asked about the genre of anime they usually watched, the responses revealed that $25 \%$ watch action anime, $19 \%$ watch Shonen (Shonen anime is directed to boys and usually discusses topics like dignity, fighting squads, and sports), $18 \%$ watched drama anime, and $18 \%$ watched reality anime (i.e., Slice of Life). Third, since most (if not all) participants in the survey were still learning Japanese informally, it was important to determine their initial level of proficiency skills. Therefore, respondents were asked to self-evaluate the following Japanese learning skills: listening, reading, writing, and speaking; the results are ranked from most frequent to least frequent, as depicted in Table 4 below.

Table 4. Proficiency skills of respondents in the self-evaluation question

\begin{tabular}{|c|c|c|c|}
\hline Listening skills & Ranking & Reading skills & Ranking \\
\hline $\begin{array}{l}\text { I can understand simple and short } \\
\text { utterances. }\end{array}$ & $60.8 \%$ & I cannot read at all. & $70.6 \%$ \\
\hline $\begin{array}{l}\text { I can understand utterances of complex } \\
\text { sentences if spoken slowly. }\end{array}$ & $22.1 \%$ & I just started and can read Kana ${ }^{1}$. & $14.7 \%$ \\
\hline $\begin{array}{l}\text { I can understand daily communication in } \\
\text { standard style (e.g., desu/masu). }\end{array}$ & $9.3 \%$ & I can read Kana but few Kanji ${ }^{2}$. & $11.3 \%$ \\
\hline $\begin{array}{l}\text { I can understand different Japanese } \\
\text { dialects. }\end{array}$ & $3.4 \%$ & I can read up to 100 Kanji. & $2 \%$ \\
\hline \multirow[t]{2}{*}{ I cannot understand at all. } & $2.9 \%$ & I can read up to 300 Kanji. & \\
\hline & & I can read up to 500 Kanji. & $0.5 \% *$ \\
\hline Native/near-native proficiency. & $1.5 \%$ & I can read up to 1000 Kanji and more. & \\
\hline Writing skills & Ranking & Speaking skills & Ranking \\
\hline I cannot write in Kanji at all. & $75 \%$ & $\begin{array}{c}\text { I can speak some words and simple } \\
\text { sentences. }\end{array}$ & $76.5 \%$ \\
\hline I can write my name and a few words. & $19.6 \%$ & I can speak with more complex sentences. & $12.7 \%$ \\
\hline \multirow[t]{2}{*}{ I can write complete sentences. } & $4.4 \%$ & I cannot speak at all. & $7.4 \%$ \\
\hline & & I can communicate and interact well. & $2.9 \%$ \\
\hline I can write a paragraph in Japanese. & $1 \%$ & Native/near-native proficiency. & $0.5 \%$ \\
\hline
\end{tabular}

\footnotetext{
*The three statements are equally ranked according to the responses.

${ }^{1}$ Kana are Japanese characters of which one symbol represents a single sound.

${ }^{2}$ Kanji are ancient Chinese picture words that are used in the Japanese writing system along with Kana.

From the respondents' perspective, it is evident that anime series significantly enhance their Japanese listening and speaking skills more than their reading and writing skills. In terms of listening proficiency, a majority of the respondents declared their ability to comprehend simple and short utterances $(60.8 \%)$. With regard to speaking proficiency, more respondents affirmed their capability to utter Japanese words and simple sentences (76.5\%). On the contrary, reading and writing skills depend on an individual's effort, commitment, and dedication. That is why these skills are less improved. In terms of the reading proficiency, most respondents agreed that they could not read Japanese based on anime resources alone (70.6\%). With respect to the writing proficiency, it is also difficult to use Kanji logographs in the writing as beginners. Thus, that justifies the $75 \%$ who agreed that they could not write in Kanji at all.
} 
With regard to the positive and negative consequences of utilizing anime as an informal learning tool, participants described their peak learning experience, they indicated that the learning process was fun, and the improvement was noticeable. Further, more benefits were also mentioned - that audio-visual inputs assisted in learning Japanese accurately and retrieving new expressions and concepts and that anime with written subtitles had a great impact since it eliminated filters and lowered stress. These benefits were compatible with those found in Devi (2005). However, most of the participants agreed that extensive exposure to electronic devices was likely to negatively impact their health and well-being. In addition, if the story reflected a fantasy world, the language used might not be beneficial in real life situations.

In short, the interest of acquiring L3 in this study is dominated by Japanese language. Arab teenagers and young adults, irrespective of their limited experience in visiting Japan or officially learning the language, make use of the Internet and smartphones to access anime series and other forms of Japanese products like manga almost every day. Their initial interest was found to be triggered by TV shows and the influence of their friends. Further, the growing interest in Japanese culture generally acted as a strong motive toward learning the language. It was evident that participants mainly relied on anime series and YouTube videos to learn the language, more commonly the action anime type. Moreover, they relied on Arabic subtitles (Note 4) and translation rather than dubbing or captions. Based on the self-judgment of their Japanese proficiency level, skills such as listening and speaking were the most enhanced skills. From a peak learning perspective, the learning process was reported to be fun and remarkable, yet consumed a lot of time behind the screen.

\subsection{Experiment Results}

This section highlights the findings obtained from the experiment in detail. First, a general overview of each group statistics is presented. In other words, a comparison of the participants proficiency scores of the reality anime group (Group A) versus the action anime group (Group B) are described. The results of the pretest and posttest are obtained through an independent sample SPSS t-test. Then, an in-depth analysis of the pretest and posttest scores per group is provided by measuring and comparing the paired sample t-test results. Finally, the findings from the test dependent variables, which includes vocabulary and grammar proficiency, are discussed as well.

The study hypothesis expects that participants in the reality anime group would outperform those in the action anime group in the posttest as compared to the pretest. In order to test this hypothesis, data obtained from the experiment's pretest and posttest scores provide a general view of each group statistics. Using independent t-test analysis, the difference between the two groups is presented in Table 5.

Table 2. Comparison of participants' scores in the reality anime and action anime groups

\begin{tabular}{ccccccc}
\hline \multirow{2}{*}{ Test * } & \multicolumn{3}{c}{ Group Statistics } & & \multicolumn{2}{c}{ Independent T-test } \\
\cline { 2 - 7 } & Group & N & Mean & Std. Deviation & t & p-value \\
\hline Pretest Scores & A & 25 & 23.80 & 8.675 & -0.574 & 0.568 \\
& B & 26 & 25.19 & 8.635 & & \\
Posttest Scores & A & 25 & 27.40 & 8.622 & 0.127 & 0.899 \\
& B & 26 & 27.08 & 9.474 & & \\
\hline
\end{tabular}

* The maximum test score is 45 .

According to the data presented in the table above, the average score achieved in the pretest by the reality anime group is 23.8 points, while the action anime group achieved a mean of 25 points. These results indicate that there is no statistically large difference between the two groups in terms of the pretest average score when calculating the scores of the independent t-test $(\mathrm{p}=0.56)$. In addition, when applying the normality test on participants under the standard count of $\mathrm{n}=30$, the results of the normality test reveal that the data follow the normal distribution (Table 3). Considering the posttest results, even though there is no salient difference in the average scores between the two groups (i.e., the average score of reality anime is 27.4 points and action anime is 27 points), the results of the independent t-test indicate a significant improvement in the posttest scores compared to the pretest scores $(\mathrm{p}=0.89>\mathrm{p}=0.56$, and both $>0.05)$.

However, the decision of which group outperformed the other group is not determined yet. Further analysis was done using the paired sample t-test in which the pretest and posttest results are compared side-by-side for participants in each group. The dependent t-test results are presented in Table 6 below. 
Table 6. Comparison of participants performance in the posttest versus the pretest in the reality and action anime groups

\begin{tabular}{|c|c|c|c|c|c|c|c|c|c|}
\hline & \multirow[b]{4}{*}{ Group } & \multicolumn{5}{|c|}{ Paired Samples Test } & \multirow[b]{4}{*}{$\mathrm{t}$} & \multirow[b]{4}{*}{$\mathrm{df}$} & \multirow[b]{4}{*}{ Sig. (two-tailed) } \\
\hline & & & \multicolumn{4}{|c|}{ Paired Differences } & & & \\
\hline & & \multirow[b]{2}{*}{ Mean } & \multirow{2}{*}{$\begin{array}{c}\text { Std. } \\
\text { Deviation }\end{array}$} & \multirow{2}{*}{$\begin{array}{l}\text { Std. } \\
\text { Error } \\
\text { Mean }\end{array}$} & \multicolumn{2}{|c|}{$\begin{array}{l}\text { 95\% Confidence } \\
\text { Interval of the } \\
\text { Difference }\end{array}$} & & & \\
\hline & & & & & Lower & Upper & & & \\
\hline A & Posttest vs. Pretest & 3.600 & 5.447 & 1.089 & 1.352 & 5.848 & 3.305 & 24 & 0.003 \\
\hline B & Posttest vs. Pretest & 1.885 & 2.304 & 0.452 & 0.954 & 2.815 & 4.172 & 25 & 0.000 \\
\hline
\end{tabular}

Beginning with the reality anime group, the average score of the pretest is 23.8 and the average score of the posttest is 27.4. In order to see if there is a significant difference between the pretest and posttest scores in this group, the paired t-test results are used. The results reveal that the p-value of 0.003 is less than 0.05 , and considering the maximum score of 45 , the p-value indicates that there is a statistically significant difference in the posttest for those who watch reality anime compared to their pretest results. Moreover, the average increase in the posttest results is 3.6 points among all participants in this group.

With regard to the action anime group, the average score of the pretest is 25 and the average score of the posttest is only 27. Despite the fact that the p-value shows a difference between the pretest and posttest results, $\mathrm{p}$-value $=0.00<0.05$, the average amount of increase among all participants who watch action anime is only 1.8 points compared to those who watch reality anime which is 3.6 average increase. In other words, the paired t-test results indicate a positive impact of anime on the posttest scores in both groups; however, participants in the reality anime group show a higher degree of improvement. Figure (4) below visually compares the performance of participants who consumed reality anime with other participants who consumed action anime.

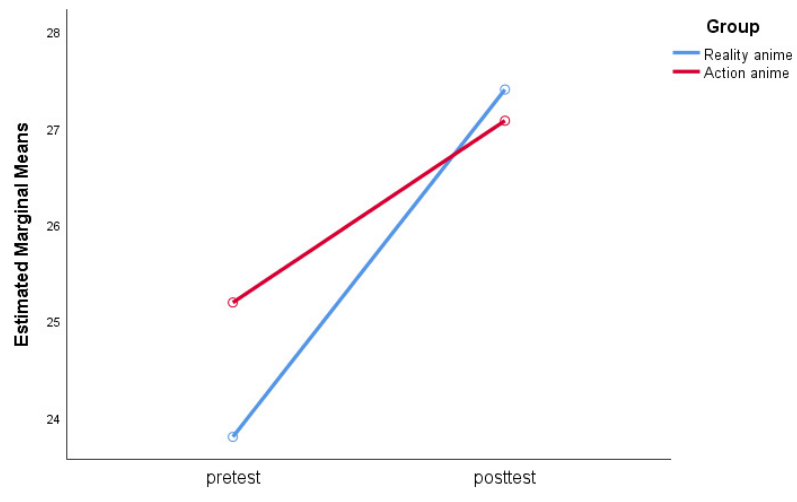

Figure 4. Visual statistics that illustrate the participants' performance in the experiment by comparing the means With regard to vocabulary and grammar development, in the reality anime group, participants achieved an increase of 69 points in the vocabulary section in the posttest, while members of the action anime group achieved an increase of 26 points. From these results it is evident that the anime genre highly affects incidental vocabulary learning. Reality anime tends to enhance the acquisition of vocabulary more than action anime as the events along the story line probably increase enthusiasm and are a lot more distracting. In terms of grammar development, the reality anime group achieved an increase of 21 points in the posttest compared to the pretest; the action anime group achieved an increase of 25 points in the posttest compared to the pretest. Nonetheless, it appears that grammar is not affected by the genre and both groups have developed a certain aspect of grammar irrespective of the content of the consumed anime.

\section{Discussion}

From a theoretical perspective, the survey findings indicate that the consumption of anime series is a result of leisure and daily life activities; moreover, Japanese language learning in this case is a relatively incidental type of learning, which makes the current study consistent with the European Commission's definition of informal 
learning (2001). Further, the relationship between informal Japanese language learning and theories of language acquisition is salient in terms of the innatism and constructivist theories. With regard to the innatism view, respondents in this study were exposed to anime as an authentic audio-visual kind of input. In addition, the learning progress is constructive in a manner that the learning process is self-governed and centered around the learners needs and desires. In other words, respondents can add new information over their previous knowledge gained from utilizing such input. Therefore, the effectiveness of the interactionist approach on the one hand compared to that of the innatism and constructivist approaches on the other hand can clearly be challenged in our case here. That being said, the most suitable approaches to informal learning partially contradict Bahrani's typical view (2011).

Moreover, the motivations of Arabic learners for learning Japanese is multidimensional. The data collected from the online survey and the experiment indicate that the two "person in context" and "complex dynamic system" theories both failed to interpret the results of participants' motivations. In order to elaborate more, the person in context theory entails the learner's interaction with cultural and historical contexts during the learning process which is not feasible in this case. Besides, the person-in-context theory has not established a complete model of analysis that accommodates motivation in every aspect, as noted by Dörnyei and Ushioda (2011). Further, complex dynamic system theory predicts three levels of analysis that are significantly correlated (i.e., motivation, cognition, and effect). However, it is difficult to implement an optimal model that addresses these levels together, and the theory is too recent to be adopted in this study. In addition, the cognition aspect of the theory involves measuring individuals' cognitive abilities and differences, both of which are difficult to predict and control.

Therefore, the findings obtained from the survey and experiment indicates that L2 motivational self-system is the most suitable motivational theory in this case. The fundamental reason for adopting this theory is the strong divergence found in the self-judgment question compared to the pretest results of all participants. In other words, participants generally rated themselves very low in the self-evaluation question (as shown in Table 4), while their actual results in the pretest are considerably high in terms of taking the test for the first time (e.g., in Table 5 , the average score in the pretest ranges between 23 and 25 out of 45 for both groups). This could be attributed to the idea that participants tend to underestimate themselves, thinking that there is a level of proficiency they ought to possess. Consequently, the L2 motivational self-system theory is implemented to account for such divergence.

Since the current study addresses Japanese as a third language, using L3 instead of L2 will be more accurate in interpreting the results. Then, the theory of L3 motivational self-system encompasses the following three dimensions: The Ideal L3 Self, the Ought-to L3 Self, and the L3 Learning Experience. With regard to the first dimension, participants who showed a great interest in Japanese language and culture reflect an integrative type of motive toward their Ideal L3 Self. In addition, a few participants who declared their need to improve their drawing skills also show an instrumental motive for developing their Ideal L3 Self. Taking into account the second dimension, the Ought-to L3 Self, participants showed both extrinsic and instrumental motives. In other words, participants who believed that Japanese language is unique were extrinsically motivated, while others who anticipated a future plan or career were instrumentally motivated toward what they think they ought to be. The last dimension of the L3 Learning Experience takes place in an informal environment. Participants affirmed that they were learning Japanese informally with the purpose of "watching anime without subtitles." These findings are in line with those of extant research (Csizér and Kormos, 2009; Taguchi et al., 2009), but they are relatively new in predicting and interpreting the motivations of Arabic native speakers in light of SLA motivational theories.

In summary, the experiment results indicate that there is a significant improvement in the posttest scores compared to the pretest scores. This is an indication of the positive effect of Japanese anime on informal third language learning. Moreover, it is found that reality anime group outperformed the action anime group in terms of one aspect of Japanese proficiency test-vocabulary learning. However, the findings also indicate that the two groups equally improved in terms of grammar competence regardless of the anime selection and this result contradicts with Han \& Ling's (2017) anime selection view. In essence, the selection of anime based on genre could be distractive or constructive in learning vocabulary, but it could be constructive in incidental learning of basic grammar rules. The reason in this case could be attributed to the fact that grammar is related to and affected by language usage rather than the type of content presented in any anime series.

\section{Conclusion, Limitations, and Implications}

The findings of the online survey indicate that Arabic native speakers are highly motivated to informally learn Japanese as a third language. Even though some participants tended to underestimate themselves in terms of 
Japanese language proficiency, the results of the experiment indicate the following aspects: a) their motivation to learn Japanese is multidimensional according to the L2 motivational self-system theory; b) participants' consumption of anime series reveal a significant enhancement in Japanese vocabulary learning, and the acquisition of vocabulary in this case is highly influenced by the selection of anime; c) although participants did not show a significant level of grammar proficiency, they were able to elicit basic Japanese grammar rules from anime videos without instructions and irrespective of the genre selected.

Further, this study has certain limitations. First, it is still unknown what type of strategies or techniques informal learners of Japanese employed to improve their Japanese proficiency level along with watching anime series (e.g., pause, repeat and rewind scenes; memorize words and expressions; imitate characters; take notes; and divide episodes into shorter clips or learn with their peers). In addition, it is also unknown whether the high motivation of Arab teenagers and young adults will lead them to enroll into formal Japanese foreign language education. The limited literature on the topic of target Arabic speakers makes it difficult to compare the results obtained with any official statistics.

The general implications and future directions of motivation in the context of the current study and in light of informal language learning are summarized in the following manner. First, the study of motivation is an interdisciplinary field that involves further investigations of various factors related to linguistics, psychology, and education (Dörnyei \& Ushioda, 2011). It is evident that the mode of learning, the source of input, and time of exposure make a significant contribution to the learning of a foreign language, particularly expanding both the internal and external motivation of learners (Cole \& Vanderplank, 2016). Second, the integration of motivation with formal education is beneficial in enhancing the quality of learning and the students' engagement in classroom activities apart from reducing students' procrastination and dissatisfaction levels. Similarly, the incorporation of popular culture and enthusiasm into class curriculum boost students' confidence, encourage critical thinking, and breakdown cultural stereotypes (Matsumoto, 2007). Therefore, informal learning maximizes the potential learning benefits more than the duration of formal education (Peters \& Webb, 2018). Thus, teachers must emphasize the value of out-of-class exposure to TV programs, videos and films, computer games, and various websites. Moreover, teachers must encourage their students to create, share, and evaluate authentic online resources to build their digital literacy and experience and avoid imparting them with outdated skills (Warner \& Dupuy; 2018, Godwin; 2018b, Lankshear \& Knobel; 2003, Fukunaga; 2006).

With regard to the implications of animation as a learning tool, autonomous learning and self-evaluation guide informal learners to sense and observe their learning progress. Further, utilizing animation videos with subtitles is most suitable for beginners in furthering comprehension and understanding of the material presented in a foreign language. For advanced learners, it is recommended that captions be used instead of subtitles in order to enhance their reading and writing skills as well as their general linguistic knowledge (Montero; 2017, Mariotti; 2015). Further, short anime clips are more comprehensive and valuable in expanding vocabulary knowledge and grammar competence (Rodger, 2013).

Thus, it is obvious that the mindset of today's informal language learners is changing in parallel with recent advancements in technology. Consequently, further research is required in order to account for current motivations and attitudes toward informal language learning. Moreover, the effectiveness of contemporary learning tools and materials must also be addressed in future research as well. In fact, more research is needed in order to capture instances of successful informal language learning in various settings and for different purposes.

\section{References}

Allison, A. (2006). The Japan fad in global youth culture and millennial capitalism. Mechademia, 1(1), 11-21. https://doi.org/10.1353/mec.0.0048

Arıkan, A., \& Taraf, H. U. (2010). Contextualizing young learners' English lessons with cartoons: Focus on grammar and vocabulary. Procedia-Social and Behavioral Sciences, 2(2), 5212-5215. https://doi.org/10.1016/j.sbspro.2010.03.848

Armour, W. S., \& Iida, S. (2016). Are Australian fans of anime and manga motivated to learn Japanese language? Asia Pacific Journal of Education, 36(1), 31-47. https://doi.org/10.1080/02188791.2014.922459

Bahrani, T. (2011). An overview to informal language learning. Language in India, 11(8).

Bahrani, T., \& Soltani, R. (2011). The pedagogical values of cartoons. Research on Humanities and Social Sciences, 1(4), 19-22.

Benson, P. (2015). Commenting to learn evidence of language and intercultural learning in comments on Youtube videos. Language, Learning and Technology, 19(3), 88-105. 
Chik, A. (2019). Motivation and informal language learning. The Handbook of Informal Language Learning, 13-26. https://doi.org/10.1002/9781119472384.ch1

Chomsky, N. (1965). Aspects of the theory of syntax. Cambridge, Mass: MIT Press. https://doi.org/10.21236/AD0616323

Chomsky, N. (1993). Lectures on government and binding: The Pisa lectures (No. 9). Walter de Gruyter. https://doi.org/10.1515/9783110884166

Coffield, F. (Ed.). (2000). The necessity of informal learning. Bristol: The Policy Press.

Cole, J. \& Vanderplank, R. (2016). Comparing autonomous and class-based learners in Brazil: evidence for the present-day advantages of informal, out ${ }^{-}$of class learning. System, 61(1), 31-42. https://doi.org/10.1016/j.system.2016.07.007

Cook, V. (1996). Second language learning and language teaching. London, Arnold.

Csizér, K. \& Kormos, J. (2009). Learning experiences, selves and motivated learning behavior: A comparative analysis of structural models of Hungarian Secondary and University Learners of English. In Z. Dörnyei and E. Ushioda (Eds.), Motivation, language identity and the 12 self (pp. 98-119). Bristol: Multilingual Matters. https://doi.org/10.21832/9781847691293-006

Deci, E.L. \& Ryan, R.M. (1985). Intrinsic motivation and self-determination in human behavior. New York: Plenum. https://doi.org/10.1007/978-1-4899-2271-7

Devi, V. A. (2005). Using animation for teaching phrasal verbs: A brief Indian experiment. Language in India, $5(8)$.

Dörnyei, Z. \& Ushioda, E. (2011). Teaching and researching motivation, 2e. Harlow, UK: Longman.

Dörnyei, Z. (2005). The psychology of the language learner: individual differences in second language acquisition. Mahwah, NJ: Lawrence Erlbaum.

Dörnyei, Z. (2009). The L2 motivational self-system. In Z. Dörnyei and E. Ushioda (Eds.), Motivation, language identity and the 12 self (pp. 9-42). Bristol, UK: Multilingual Matters. https://doi.org/10.21832/9781847691293

Dörnyei, Z. (2009a). The L2 motivational self-system. In Dörnyei, Z. and Ushioda, E. (Eds.), Motivation, language identity and the 12 self (pp. 9-42). Bristol: Multilingual Matters. https://doi.org/10.21832/9781847691293-003

Dörnyei, Z. (2009b), The psychology of second language acquisition. Oxford: Oxford University Press.

Ellis, R. (1999). Understanding second language acquisition, Oxford University Press, Oxford.

European Commission. (2001). Communication from the Commission: Making a European area of lifelong learning a reality. Brussels.

Fukunaga, N. (2006). Those anime students: Foreign language literacy development through Japanese popular culture. Journal of Adolescent \& Adult Literacy, 50(3), 206-222. https://doi.org/10.1598/JAAL.50.3.5

Gardner, R.C. \& Lambert, W. (1972). Attitudes and motivation in second language learning. Rowley, MA: Newbury House.

George, D., \& Mallery, M. (2003). Using SPSS for Windows step by step: A simple guide and reference. Boston, MA: Allyn \& Bacon.

Godwin-Jones, R. (2018b). Restructuring intermediate language instruction with open and student-curated materials. In J. Colpaert, A. Aerts \& F. Cornillie (Eds.), CALL your DATA proceedings (pp. 144-151). Antwerp: University of Antwerp.

Han, C. Y., \& Ling, W. N. (2017). The use of anime in teaching Japanese as a foreign language. Malaysian Online Journal of Educational Technology, 5(2), 68-78.

Japanesetest4you.com. (2014). Online Japanese Proficiency Practice Tests. [online] Available at: $<\mathrm{https} / / /$ japanesetest4you.com/> [Accessed 19 January 2020].

Kayaoglu, M. N., \& Akbas, D. (2011). A small-scale experimental study: Using animations to learn vocabulary. Turkish Online Journal of Educational Technology-TOJET, 10(2), 24-30. 
Kukulska-Hulme, A. (2015). Language as a bridge connecting formal and informal language learning through mobile devices. In L.-H. Wong, M. Milrad, \& M. Specht (Eds.), Seamless learning in the age of mobile connectivity (pp. 281-294). Singapore: Springer. https://doi.org/10.1007/978-981-287-113-8_14

Lankshear, C., \& Knobel, M. (2003). New literacies: Changing knowledge and classroom learning. Buckingham, England: Open University Press.

Long, M. H. (1983). Native speaker/non-native speaker conversation and the negotiation of comprehensible input1. Applied Linguistics, 4(2), 126-141. https://doi.org/10.1093/applin/4.2.126

Mahoney, J. (2001). What is informal education? In L. D. Richardson \& M. Wolfe (Eds.), Principles and practice of informal education: learning through life (pp. 17-33). Abingdon, Oxon: RoutledgeFalmer.

Mariotti, C. (2015). A survey on stakeholders' perceptions of subtitles as a means to promote foreign language learning. In Y. Gambier, A. Caimi, \& C. Mariotti (Eds.), Subtitles and language learning (pp. 83-104). Frankfurt: Peter Lang.

Matsumoto, H. (2007). Peak learning experiences and language learning: A study of American learners of Japanese. Language, Culture and Curriculum, 20(3), 195-208. https://doi.org/10.2167/lcc335.0

Munir, F. (2016). The effectiveness of teaching vocabulary by using cartoon film toward vocabulary mastery of EFL students. Journal of English Language Teaching and Linguistics, 1(1), 13-37. https://doi.org/10.21462/jeltl.v1i1.20

Northwood, B., \& Kinoshita Thomson, C. (2012). What keeps them going? Investigating ongoing learners of Japanese in Australian universities. Japanese Studies, 32(3), 335-355. https://doi.org/10.1080/10371397.2012.735988

Peters, E., \& Webb, S. (2018). Incidental vocabulary acquisition through viewing L2 television and factors that affect learning. Studies in Second Language Acquisition, 40(3), 551-577. https://doi.org/10.1017/S0272263117000407

Pica, T. (1994). Research on negotiation: What does it reveal about second-language learning conditions, $\begin{array}{llll}\text { processes, } \quad \text { and learning, 44(3), } & \text { 493-527. }\end{array}$ https://doi.org/10.1111/j.1467-1770.1994.tb01115.x

Sade, L. A. (2011). Emerging selves, language learning and motivation through the lens of chaos. Identity, Motivation and Autonomy in Language Learning, 54, 42. https://doi.org/10.21832/9781847693747-005

Sade, L.A. (2003). Querer e ' poder, querer e poder, querer sem poder: A motivac ,a o para o aprendizado de ingle ^s na escola pu 'blica sob uma perspectiva semio 'tica social. MA dissertation, Universidade Federal de Minas Gerais.

Salkind, N. J. (Ed.). (2010). Encyclopedia of research design, 1. Thousand Oaks: SAGE Publications, Inc.

Shamoon, D. (2010). Teaching Japanese popular culture. Campagne 20152016 Rapports D'activi-TÉS, 6. https://doi.org/10.16995/ane.204

Skinner, B.F. (1957), Verbal behavior. New York: Appleton Century Crofts. https://doi.org/10.1037/11256-000

Swenson, T. (2010). What kind of culture could produce these? Appeal of the Exotic as Entry into Japanese Culture.

Taguchi, T., Magid, M., \& Papi, M. (2009). The L2 motivational self-system among Japanese, Chinese and Iranian learners of English. In Z. Dörnyei \& E. Ushioda (Eds.), Motivation, language identity and the 12 self (pp.66-97). Bristol: Multilingual Matters. https://doi.org/10.21832/9781847691293-005

The Japan Foundation. (2011). Present condition of overseas Japanese Language education: Survey report on Japanese-Language education abroad 2009. Tokyo: The Japan Foundation.

Tomlinson, B. (Ed.). (2011). Materials development in language teaching. Cambridge University Press.

Ushioda, E. (2009). A person-in-context relational view of emergent motivation, self and identity. In Dörnyei, Z. \& E. Ushoda (Eds.), motivation, language identity and the $l 2$ self (pp.215-218). Bristol: Multilingual Matters. https://doi.org/10.21832/9781847691293-012

Van Marsenille, A. (2015). Informal language learning: the perspective of higher education students in Brussels. A case study. Doctoral thesis. The Open University. 
Van Marsenille, A. (2017). Informal learning activities for learners of English and for learners of Dutch. In Q. Kan \& S. Bax (Eds.), Beyond the language classroom: researching MOOCs and other innovations (pp. 141-152). Research-publishing.net. https://doi.org/10.14705/rpnet.2017.mooc2016.677

Vélez Gea, N. L. (2013). Learning and teaching of English in a foreign language classroom of primary education through current songs and cartoons. Odisea, 14, 183-204.

Warner, C. \& Dupuy, B. (2018). Moving toward multiliteracies in foreign language teaching: past and present perspective and beyond. Foreign Language Annals, 51, 116-128. https://doi.org/10.1111/flan.12316

Wright, K. B. (2005). Researching internet-based populations: Advantages and disadvantages of online survey research, online questionnaire authoring software packages, and web survey services. Journal of Computer-Mediated Communication, 10(3). https://doi.org/10.1111/j.1083-6101.2005.tb00259.x

\section{Notes}

Note 1. Lingua franca usually refers to a third language used for communication among native speakers of two distinct languages, also known as bridge language (Oxford dictionary).

Note 2. Peak learning experience is a concept developed by Bloom (1982) based on Maslow's Peak Experience $(1959,1970)$. It is focused on investigating classroom motivational factors and their integration into research.

Note3. The titles of reality anime series used in this study were Silver Spoon seasons $1 \& 2$, Shirobako, and Barakamon, while the action anime series were Ajin, 91 Days, Kabaneri of the Iron Fortress, and Vinland Saga.

Note 4 . It was found that 15 participants in the online survey were actually working or volunteering in the anime industry, specializing in voice acting, producing, and translating the anime content into Arabic.

\section{Appendix A}

The survey questionnaire sample

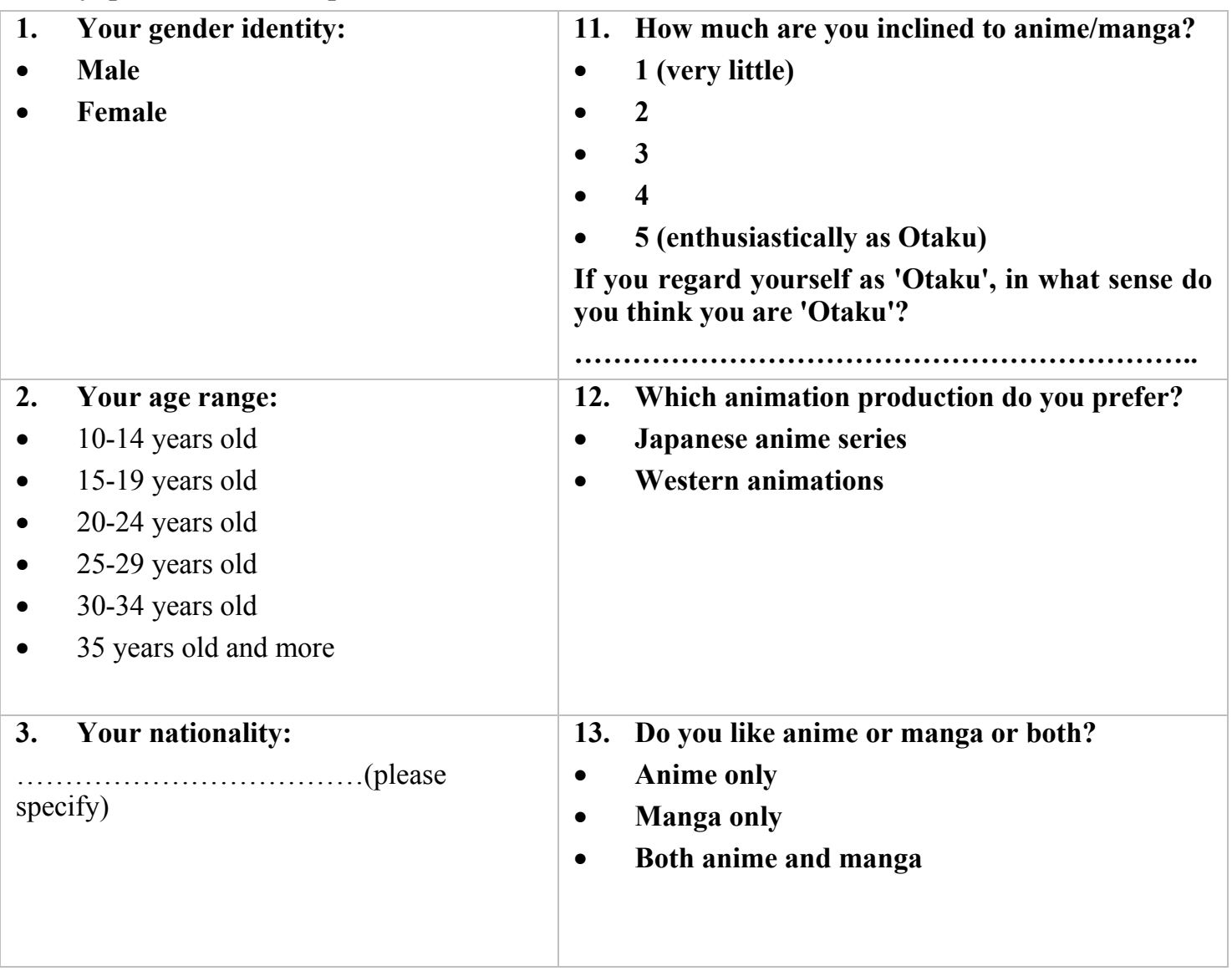


4. Your native language:

- Arabic

- Other. (please specify)
14. How often do you watch anime?

- Every day

- Once every few days

- Once a week

- Once every few weeks

- Once a month

- Rarely

- never

15. How long in average do you watch anime at a time?

- Less than one hour

- 2 hours

- 3 hours

- Other.......(please specify)

6. A language you are interested to learn as L3:

- French

- Japanese

- Chinese

- Korean

- Spanish

- Other (please specify)

7. You live with:

- No one

- Parents

- Siblings without parents

- Relatives

- Friends

- Flat mate

- Host family

8. Have you been to Japan before?

- Yes

- No
16. How long have you been watching anime?

- Less than a year

- 1-2 years

- 3-4 years

- 5 years and more

17. What triggered you the most to watch anime?

- $\quad$ Friend

- Family member

- TV program

- Magazine

- Comics at bookstores

- Internet and fan sites

18. What genre of anime do you watch?

- Action

- Drama

- Comedy

- Historical

- Horror

- Slice of life

- Psychological

- Shonen

- Fantasy

- Mystery

- Sci-fi

- Shoujo

19. Are you a heritage speaker of Japanese?

- Yes

- No

- Once

- Twice

- 3-4 times

- 5 times and more 
10. Total length of your stay in Japan is: (please specify)
20. Have you ever studied Japanese formally before?

- Yes

- No

21. If yes, where did you study Japanese?

- At school

- At collage as a course

- Private institute

- Private tutor

22. How long have you studied Japanese? days/months/years

23. If you didn't study Japanese formally, how did you learn it informally?

- Self-learning via YouTube

- Friends

- Anime only

- Video games

- Social media

- Contact with natives

24. How long have you been learning Japanese?

- 3 months

- 6 months

- 1 year

- 2 years and more

25. What motivates you the most to learn Japanese?

- Interest in culture in general

- Planning to work or study there

- Watch anime without subtitles or translations

- Improve drawing skills

- The language is unique

Which of the following describe your current Japanese proficiency level the best?
31. Are you motivated to study Japanese by anime?

- Not motivated

- 1

- 2

- 3

- 4

- 5 (highly motivated)

32. If you are not learning Japanese now or have learned Japanese, are you interested in learning Japanese because of your interest in anime?

- Not interested

- 1

- 2

- 3

- 4

- 5 (very interested)

33. In what language do you watch anime?

- In Japanese with Arabic subtitles

- In Japanese with English subtitles

- In Japanese with Kanji subtitles

- Only Japanese without subtitles

- Arabic dubbing

- English dubbing

34. Have you ever had an experience in fan subbing?

- Yes

- No

If yes, what is the name of the site?

35. Have you ever been involved in anime conventions?

- Yes

- No

If yes, please specify 
26. Reading:

- Cannot read at all

- Just started and can read Kana

- Can read Kana but few Kanji

- Can read up to $100 \mathrm{kanji}$

- Can read up to $300 \mathrm{Kanji}$

- $\quad$ Can read up to $500 \mathrm{Kanji}$

- Can read up to $800 \mathrm{Kanji}$

- Can read up to $1000 \mathrm{Kanji}$ and more

- Near native level

27. Listening:

- Cannot understand at all

- Can understand simple and short utterances

- Can understand utterances of complex sentences if spoken slowly

- Can understand daily communication in standard style(desu/masu)

- Can understand different Japanese dialects

- Native/near native

28. Writing:

- Cannot write at all

- Can write my name and few words

- Can write complete sentences

- Can write a paragraph in Japanese

- Can write an essay in Japanese

29. Speaking skills

- Cannot speak at all

- Can speak some words and simple sentences

- Can speak with complex sentences

- Can communicate and interact

- Native/near native

30. Grammar:

- I do not know grammar at all

- I know word order

- I know negation rules

- I know Wh-Q formation

- I know yes/no Q formation

- I know more complex rules
36. From your viewpoint, what are the advantages of learning Japanese via anime?

- Learning is fun and the improvement is noticeable

- Remove affective filters (curriculum)

- Lower stress and anxiety level

- Easier retrieving of new words and expressions

- Subtitles aid understanding

- Audio-visual input assists accurate learning

37. From your viewpoint, what are the disadvantages of learning Japanese via anime?

- Watching the anime repeatedly

- Spending a lot of time behind the screen may affect health

- May lead to learn inappropriate language

- Language of fantasy story may not be fruitful

- Learning is inconsistent and boring

38. Why do you think anime gained its popularity internationally and in Arabic world specifically?

- Discuss varieties of issues

- Comics are fun

- Detailed and continuous storyline

- Deeply involved relationships

- High quality voices

- Creativity

- Target varieties of ages

39. Would you like to participate in an experiment concern with anime?

- Yes

- No

If yes, please type in your contact info....................................... 


\section{Appendix B}

\section{The experiment test sample}

\section{$\underline{\text { Japanese language proficiency test }}$}

\section{Part 1: Vocabulary test}

Q1: You are, kindly, requested to choose the correct answer from 1, 2, 3 and 4 to make meaningful sentences.

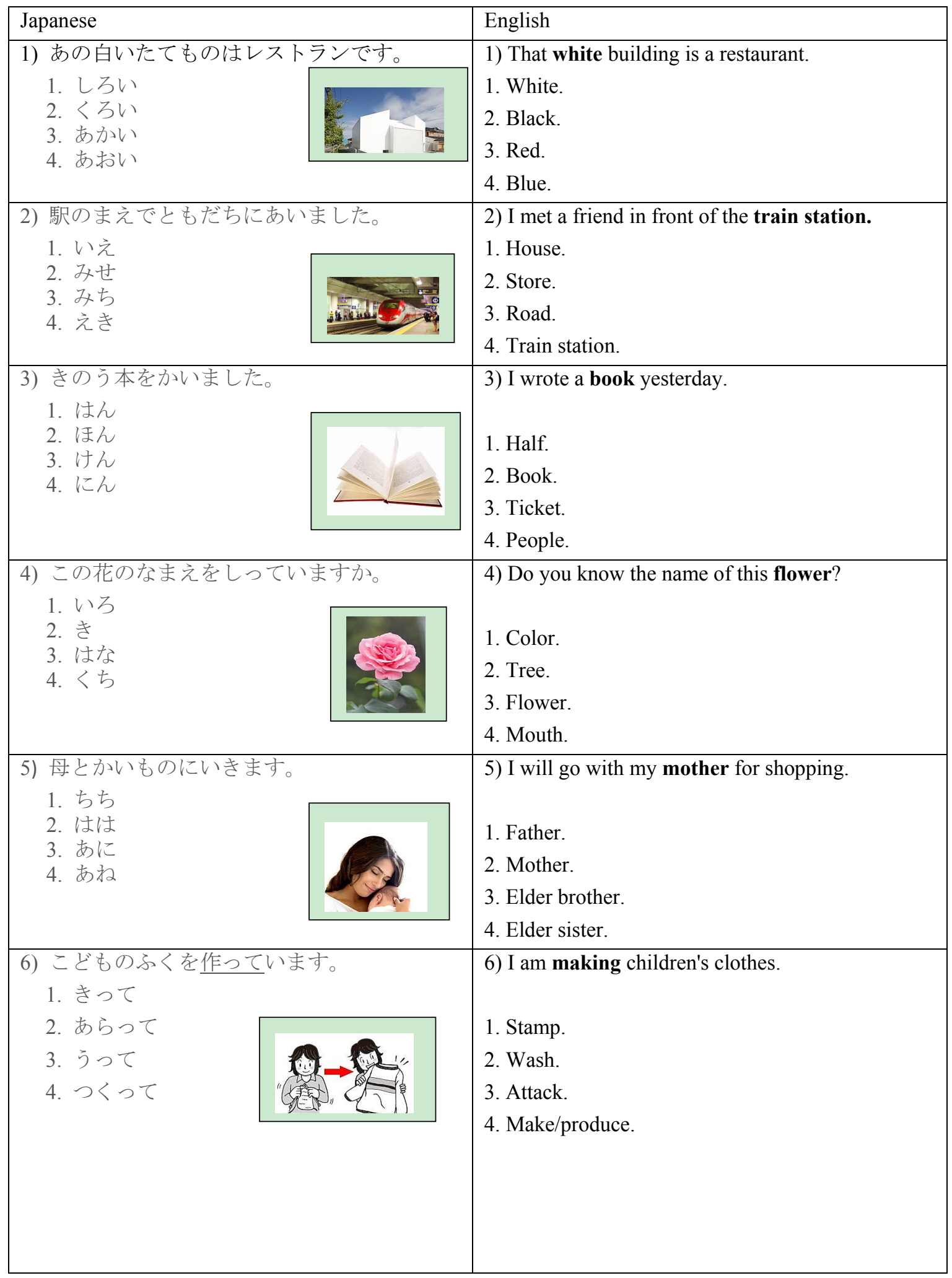




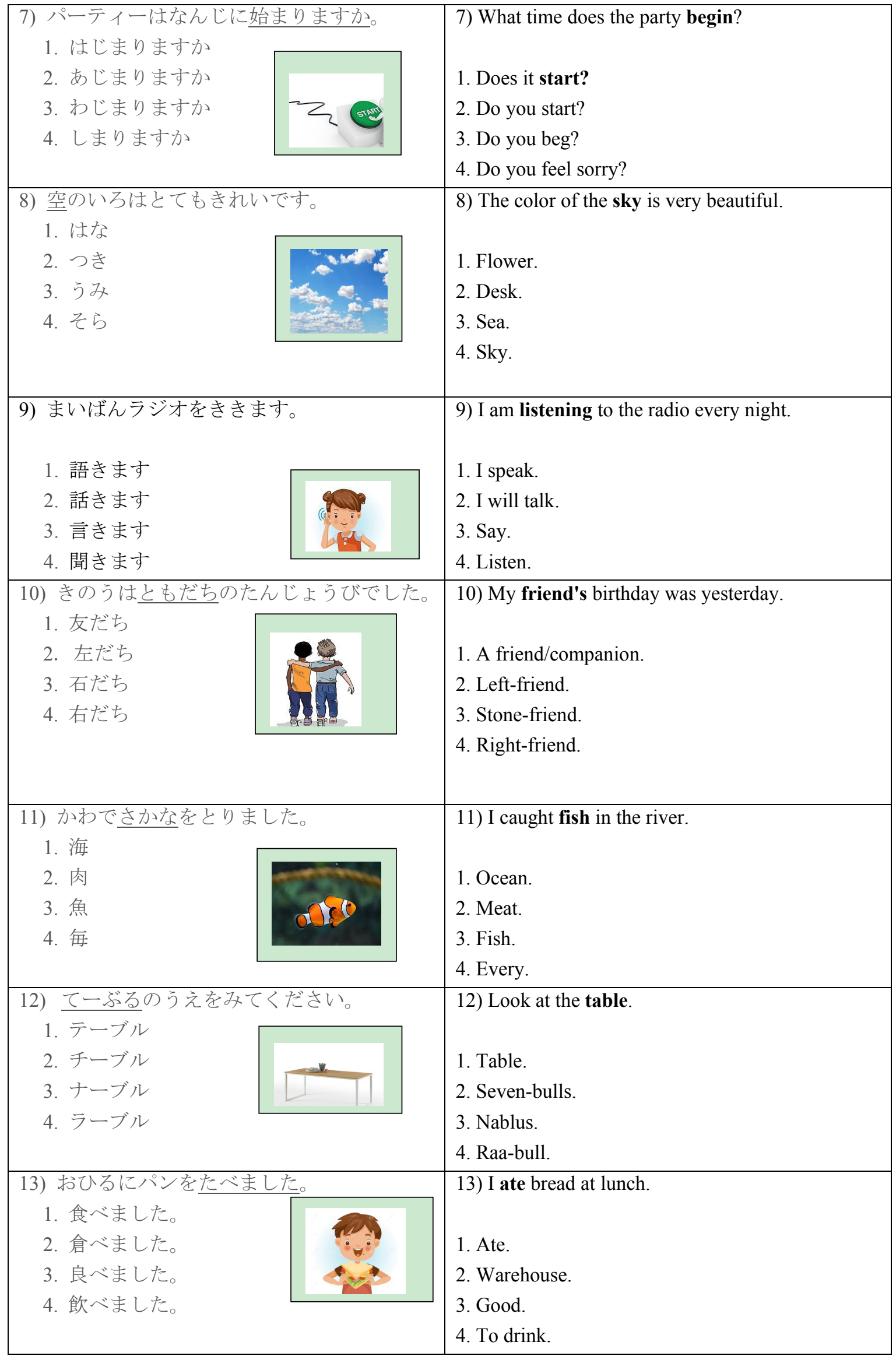




\begin{tabular}{|c|c|}
\hline 14) デパートでシャツをかいました。 & 14) I bought a shirt at a department store. \\
\hline $\begin{array}{l}\text { 1. 音いました。 } \\
\text { 2. 員いました。 } \\
\text { 3. 買いました。 } \\
\text { 4. 貝いました。 }\end{array}$ & $\begin{array}{l}\text { 1. To be noisy. } \\
\text { 2. Was a member. } \\
\text { 3. I bought it. } \\
\text { 4. I had a shellfish. }\end{array}$ \\
\hline $\begin{array}{l}\text { 15) まいあさ（ ）をのみます。 } \\
\text { 1. にく } \\
\text { 2. おちや } \\
\text { 3. おかし } \\
\text { 4. やさい }\end{array}$ & $\begin{array}{l}\text { 15) I drink () every morning. } \\
\text { 1. Meat. } \\
\text { 2. Tea. } \\
\text { 3. Candy. } \\
\text { 4. Vegetable. }\end{array}$ \\
\hline $\begin{array}{l}\text { 16)（ ）をかぶります。 } \\
\text { 1. うわぎ } \\
\text { 2. ズボン } \\
\text { 3. ぼうし } \\
\text { 4.くつ }\end{array}$ & $\begin{array}{l}\text { 16) Put on a (). (on one's head) } \\
\text { 1. Coat, outerwear. } \\
\text { 2. Trousers. } \\
\text { 3. Hat. } \\
\text { 4. Shoes. }\end{array}$ \\
\hline $\begin{array}{l}\text { 17) このふくには（ ）があります。 } \\
\text { 1. アパート } \\
\text { 2. コート } \\
\text { 3. カレンダー } \\
\text { 4. ポケット }\end{array}$ & $\begin{array}{l}\text { 17) There are () in these clothes. } \\
\text { 1. Apartment. } \\
\text { 2. Coat. } \\
\text { 3. Calendar. } \\
\text { 4. Pockets. }\end{array}$ \\
\hline $\begin{array}{l}\text { 18) ここでみちを（ ）ましょう。 } \\
\text { 1. とまり } \\
\text { 2. わたり } \\
\text { 3. とり } \\
\text { 4. ならび }\end{array}$ & $\begin{array}{l}\text { 18) Let us cross the road. } \\
\text { 1. Stopover. } \\
\text { 2. To cross over/to go across. } \\
\text { 3. Bird. } \\
\text { 4. Line. }\end{array}$ \\
\hline $\begin{array}{l}\text { 19) ここでくつを（ ）ください。 } \\
\text { 1. きて } \\
\text { 2. はって } \\
\text { 3. はしって } \\
\text { 4. ぬいで }\end{array}$ & $\begin{array}{l}\text { 19) Please put your shoes here. } \\
\text { 1. To Come. } \\
\text { 2. End. } \\
\text { 3. To Run. } \\
\text { 4. Take off. }\end{array}$ \\
\hline $\begin{array}{l}\text { 20) あのでんしやはこのえきには（）ません。 } \\
\text { 1. けし } \\
\text { 2.で } \\
\text { 3.ならび } \\
\text { 4. とまり }\end{array}$ & $\begin{array}{l}\text { 20) That train does not (stop) in this area. } \\
\text { 1. Poppy. } \\
\text { 2. An indicator. } \\
\text { 3. Line/arrange. } \\
\text { 4. Stop. }\end{array}$ \\
\hline
\end{tabular}




\begin{tabular}{|c|c|}
\hline $\begin{array}{l}\text { 21) おたしのりょうしんは（ ）げんきだ。 } \\
\text { 1. わかくて } \\
\text { 2. あたらしくて } \\
\text { 3. ふるくて } \\
\text { 4. ひろくて }\end{array}$ & $\begin{array}{l}\text { 21) My parents are (). } \\
\text { 1. Young/youthful. } \\
\text { 2. New. } \\
\text { 3. Old/ancient. } \\
\text { 4. Wide. }\end{array}$ \\
\hline $\begin{array}{l}\text { 22) このぶどうは（ ）おいしいです。 } \\
\text { 1. あまくて } \\
\text { 2. あぶなくて } \\
\text { 3. たのしくて } \\
\text { 4. すずしくて }\end{array}$ & $\begin{array}{l}\text { 22) This grape is sweet and tasty/delicious. } \\
\text { 1. Sweet. } \\
\text { 2. Dangerous. } \\
\text { 3. Fun/enjoyable. } \\
\text { 4. Cool/refreshing. }\end{array}$ \\
\hline $\begin{array}{l}\text { 23）（）なにもみえません。 } \\
\text { 1. あかくて } \\
\text { 2. さむくて } \\
\text { 3. くらくて } \\
\text { 4. あぶなくて }\end{array}$ & $\begin{array}{l}\text { 23) } 0 \text { I cannot see anything. } \\
\text { 1. Red. } \\
\text { 2. It is cold. } \\
\text { 3. It is dark. } \\
\text { 4. It is dangerous. }\end{array}$ \\
\hline $\begin{array}{l}\text { 24) このカメラは安いです。 } \\
\text { 1. たかい } \\
\text { 2. やすい } \\
\text { 3. おもい } \\
\text { 4. かるい }\end{array}$ & $\begin{array}{l}\text { 24) This camera is cheap. } \\
\text { 1. High. } \\
\text { 2. Cheap. } \\
\text { 3. Heavy. } \\
\text { 4. Light. }\end{array}$ \\
\hline $\begin{array}{l}\text { 25) なまえを（）。すみません、もういちど } \\
\text { おしえてください。 } \\
\text { 1. わかりました } \\
\text { 2. わたしました } \\
\text { 3. わすれました } \\
\text { 4. わたりました }\end{array}$ & $\begin{array}{l}\text { 25) () your name. I am sorry, please tell me again. } \\
\text { 1. I understand. } \\
\text { 2. I gave. } \\
\text { 3. I forgot. } \\
\text { 4. I passed. }\end{array}$ \\
\hline $\begin{array}{l}\text { 26)きょうのしけんは（）。ぜんぶわかった。 } \\
\text { 1. やすかった。 } \\
\text { 2. やさしかった。 } \\
\text { 3. むずかしかった。 } \\
\text { 4. すずしかった。 }\end{array}$ & $\begin{array}{l}\text { 26) Today's exam was (). I understand/know } \\
\text { everything. } \\
\text { 1. It was cheap. } \\
\text { 2. It was easy. } \\
\text { 3. It was difficult. } \\
\text { 4. It was refreshing. }\end{array}$ \\
\hline
\end{tabular}




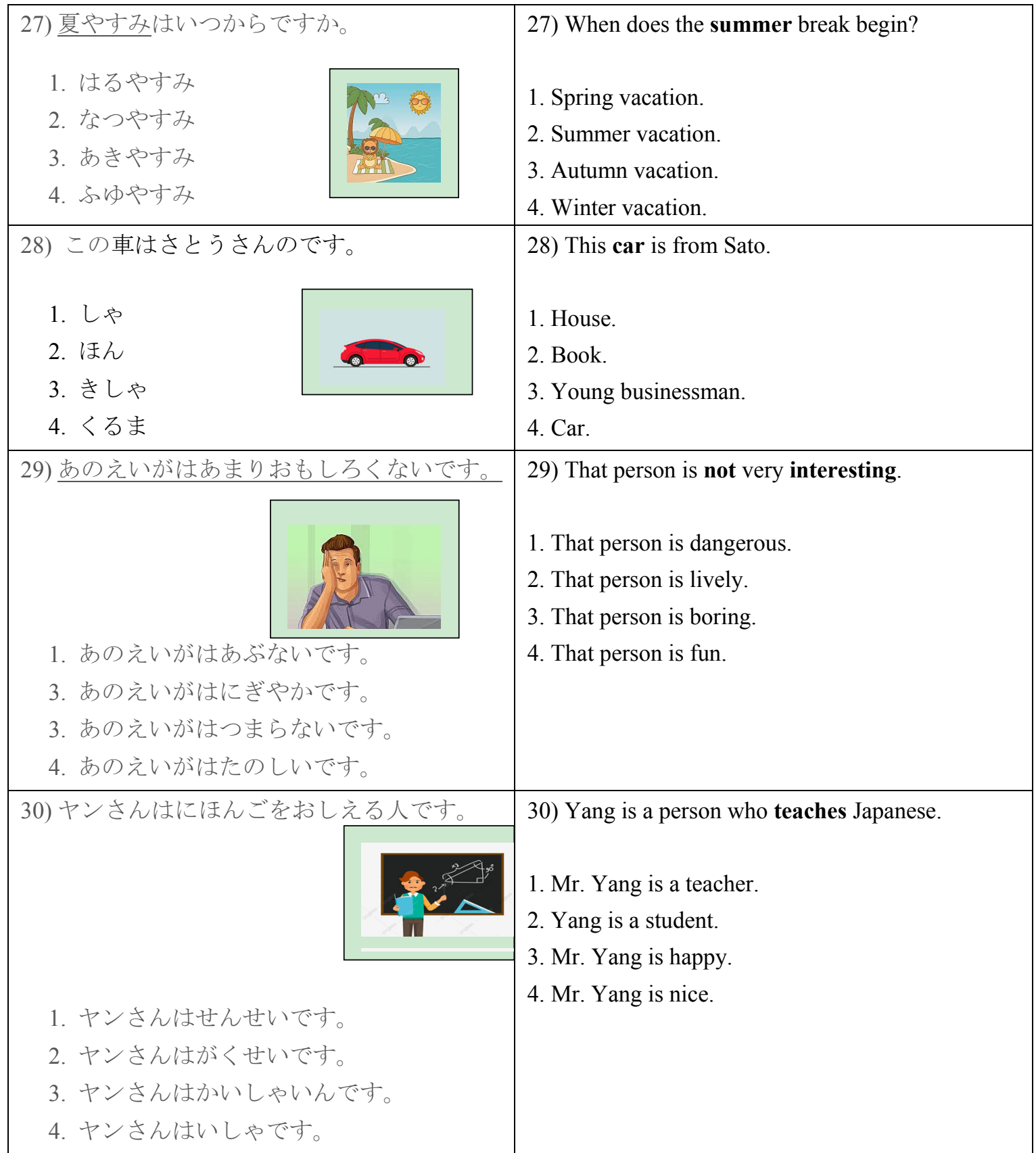




\section{Part 2: Grammar test}

Q1: You are, kindly, requested to choose the correct answer from 1, 2, 3 and 4 to make grammatical sentences.

\begin{tabular}{|c|c|}
\hline Japanese & English \\
\hline $\begin{array}{l}\text { 1) うち( ) 会社まで } 30 \text { 分かかります。 } \\
\text { 1. には } \\
\text { 2. から } \\
\text { 3. へも } \\
\text { 4. とは }\end{array}$ & $\begin{array}{l}\text { 1) It takes } 30 \text { minutes (from) home to the } \\
\text { company. } \\
\text { 1. For } \\
\text { 2. From } \\
\text { 3. Indicator } \\
\text { 4. The }\end{array}$ \\
\hline $\begin{array}{l}\text { 2)きよねんの3月（）日本へ来ました。 } \\
\text { 1. が } \\
\text { 2.を } \\
\text { 3. で } \\
\text { 4. に }\end{array}$ & $\begin{array}{l}\text { 2) Last year (in) March, I came to Japan. } \\
\text { 1. Is } \\
\text { 2. O-indicator } \\
\text { 3. At } \\
\text { 4. In }\end{array}$ \\
\hline $\begin{array}{l}\text { 3) おなかが（）食べられません。 } \\
\text { 1. いたい } \\
\text { 2. いたかかった } \\
\text { 3. いたくて } \\
\text { 4. いたくない }\end{array}$ & $\begin{array}{l}\text { 3) I cannot eat because my stomach is (hurting) } \\
\text { me. } \\
\text { 1. Ouch. } \\
\text { 2. It took. } \\
\text { 3. Hurting. } \\
\text { 4. Painless. }\end{array}$ \\
\hline $\begin{array}{l}\text { 4) ドアを（）ください。 } \\
\text { 1. しめる } \\
\text { 2. しめします } \\
\text { 3. しめて } \\
\text { 4. しめた }\end{array}$ & $\begin{array}{l}\text { 4) Could you please (close) the door. } \\
\text { 1. To tie. } \\
\text { 2. To show. } \\
\text { 3. Close. } \\
\text { 4. All right. }\end{array}$ \\
\hline $\begin{array}{l}\text { 5) きょうはまだ何も（）。 } \\
\text { 1. 食べました。 } \\
\text { 2. 食心゙ないでした。 } \\
\text { 3. 食べていました。 } \\
\text { 4. 食べていません。 }\end{array}$ & $\begin{array}{l}\text { 5) Today, I did not (eat) anything yet. } \\
\text { 1. I ate. } \\
\text { 2. Did not eat. } \\
\text { 3. I was eating. } \\
\text { 4. I do not eat. }\end{array}$ \\
\hline $\begin{array}{l}\text { 6) きのうは（）。 } \\
\text { 1. あつくでした。 } \\
\text { 2. あつかつた。 } \\
\text { 3. あついです。 } \\
\text { 4. あついかつたです。 }\end{array}$ & $\begin{array}{l}\text { 6) Yesterday (was hot) } \\
\text { 1. Became hot. } \\
\text { 2. Was hot. } \\
\text { 3. Is hot. } \\
\text { 4. Was being hot. }\end{array}$ \\
\hline
\end{tabular}




\begin{tabular}{|c|c|}
\hline 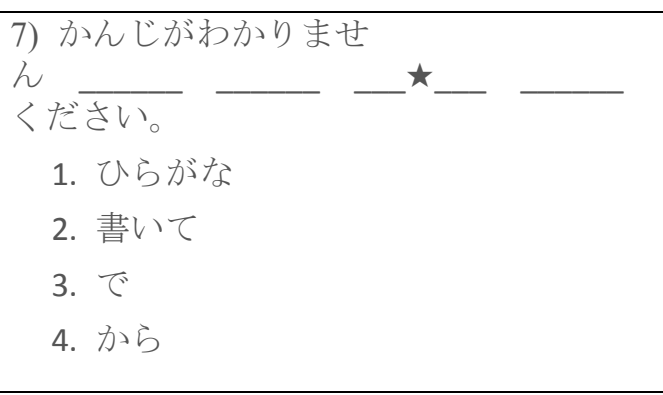 & $\begin{array}{l}\text { 7) Because I do not understand kanji, please write } \\
\text { it for me (by) hiragana. } \\
\text { 1. Hiragana (syllabification). } \\
\text { 2. To write. } \\
\text { 3. By. } \\
\text { 4. From. }\end{array}$ \\
\hline $\begin{array}{l}\text { 8) 休みの日、へ } \\
\text { や—`——— - - } \\
\text { 1. の } \\
\text { 2. そうじ } \\
\text { 3. を } \\
\text { 4. したいです }\end{array}$ & $\begin{array}{l}\text { 8) In the day off, I will do room's (cleaning). } \\
\text { 1. Of (possessive). } \\
\text { 2. Cleansing. } \\
\text { 3. To. } \\
\text { 4. Want to do. }\end{array}$ \\
\hline $\begin{array}{l}\text { 9) かぜのときはこのくすりを（）く } \\
\text { ださい。 } \\
\text { 1. のりて } \\
\text { 2. のんで } \\
\text { 3. のって } \\
\text { 4. のむで }\end{array}$ & $\begin{array}{l}\text { 9) If you have a cold, please (drink) this medicine. } \\
\text { 1. Ride. } \\
\text { 2. Drink. } \\
\text { 3. Get in. } \\
\text { 4. Take. }\end{array}$ \\
\hline $\begin{array}{l}\text { 10) 子ども「いただきます。」 } \\
\text { 母「あ、食べる }(） \text { 手をあらいましょ } \\
\text { う。」 } \\
\text { 1. まえに } \\
\text { 2. のまえに } \\
\text { 3. あとに } \\
\text { 4. のあとに }\end{array}$ & $\begin{array}{l}\text { 10) "expression of gratitude before meals." } \\
\text { Mother "Oh, let's wash our hands () eating." } \\
\text { 1. Before } \\
\text { 2. Of before. } \\
\text { 3. Later } \\
\text { 4. Of after }\end{array}$ \\
\hline $\begin{array}{l}\text { 11) 駅までタクシーで } 1000 \text { 円（） で } \\
\text { す。 } \\
\text { 1. ぐらい } \\
\text { 2. など } \\
\text { 3. ごろ } \\
\text { 4. も }\end{array}$ & $\begin{array}{l}\text { 11) It is () } 1000 \text { yen by taxi to the station. } \\
\text { 1. About. } \\
\text { 2. Such. } \\
\text { 3. Around (time) } \\
\text { 4. Also/too. }\end{array}$ \\
\hline $\begin{array}{l}\text { 12)としょかんへ本を（）行きます。 } \\
\text { 1. かりて } \\
\text { 2. かりに } \\
\text { 3. かりた } \\
\text { 4. かりる }\end{array}$ & $\begin{array}{l}\text { 12) I will () a book from the library. } \\
\text { 1. Borrower. } \\
\text { 2. Borrow. } \\
\text { 3. Borrowed. } \\
\text { 4. To borrow. }\end{array}$ \\
\hline
\end{tabular}




\begin{tabular}{|c|c|}
\hline $\begin{array}{l}\text { 13) ラジオを（） ベんきょうします。 } \\
\text { 1. 聞きます } \\
\text { 2. 聞きながら } \\
\text { 3. 聞きに } \\
\text { 4. 聞くと }\end{array}$ & $\begin{array}{l}\text { 13) I am studying () to the radio. } \\
\text { 1. To listen } \\
\text { 2. While listening } \\
\text { 3. Hearing. } \\
\text { 4. When I hear. }\end{array}$ \\
\hline $\begin{array}{l}\text { 14) 時間がすこししか（）。 } \\
\text { 1. あります } \\
\text { 2. ありません } \\
\text { 3. ある } \\
\text { 4. あるじやない }\end{array}$ & $\begin{array}{l}\text { 14) There is a (little) time }() \text {. } \\
\text { 1. There is more. } \\
\text { 2. There is not enough. } \\
\text { 3. Is there } \\
\text { 4. Is not it. }\end{array}$ \\
\hline $\begin{array}{l}\text { 15) みなさん、（）してください。 } \\
\text { 1. しずか } \\
\text { 2. しずかな } \\
\text { 3. しずかだ } \\
\text { 4. しずかに }\end{array}$ & $\begin{array}{l}\text { 15) Everyone, please be }() \text {. } \\
\text { 1. Slow. } \\
\text { 2. Quietly } \\
\text { 3. Has quiet. } \\
\text { 4. Quiet }\end{array}$ \\
\hline
\end{tabular}

\section{Copyrights}

Copyright for this article is retained by the author(s), with first publication rights granted to the journal.

This is an open-access article distributed under the terms and conditions of the Creative Commons Attribution license (http://creativecommons.org/licenses/by/4.0/). 